Earth and Environmental Science Transactions of the Royal Society of Edinburgh, Volume 102, 201-225, 2012 (for 2011).

Note that this version of the text may not include all of the final editorial amendments added in proof. For the fossil plates the cited scales apply to the size of the images as reproduced in EESTRSE and may not be correct for a download derived from this site.

\title{
An Early Cambrian archaeocyath-trilobite fauna in limestone erratics from the Upper Carboniferous Fitzroy Tillite Formation, Falkland Islands
}

P. Stone ${ }^{1}$, M. R. A. Thomson ${ }^{2}$ and A. W. A. Rushton ${ }^{3}$

${ }^{1}$ British Geological Survey, Murchison House, West Mains Road, Edinburgh EH9 3LA UK.

Email: psto@bgs.ac.uk

${ }^{2}$ School of Earth and Environment, University of Leeds, Leeds LS2 9JT, UK.

${ }^{3}$ Department of Palaeontology, The Natural History Museum, Cromwell Road, London SW7 5BD, UK and British Geological Survey, Keyworth, Nottingham NG12 5GG, UK.

Running heads: $\quad$ LH: P. Stone et al.

RH: An archaeocyath-trilobite fauna, Falkland Islands 
ABSTRACT: Rare clasts of limestone contained in the uppermost Carboniferous Fitzroy Tillite Formation of the Falkland Islands contain a rich Cambrian fauna of archaeocyaths together with a radiocyath and a few trilobites. Neither Cambrian strata nor limestone are present in the indigenous rock succession and the clasts are regarded as exotic erratics, introduced during the Permo-Carboniferous glaciation of southern Gondwana, prior to its Mesozoic break-up. Nineteen archaeocyath taxa have been identified, with seven (plus a radiocyath) occurring in a single clast. Trilobite identifications are less definitive but they are compared to Yorkella and the Siberian genera Edelsteinaspis, Namanoia and Chondrinouyina. The archaeocyath fauna has an Australo-Antarctic character and the Transantarctic Mountains seem the most likely source for these unusual erratics. Most recent reconstructions of Gondwana rotate a Falklands microplate into a position between South Africa and East Antarctica. There, it is in proximity with the Eastern Cape Province, where tillites within the Permo-Carboniferous Dwyka Group are correlatives of the Fitzroy Tillite Formation, and the 'Atlantic' end of the Transantarctic Mountains. The Dwyka Group tillites also contain rare clasts of archaeocyathan limestone and the rotational reconstruction produces a continuity of the apparent ice-flow directions in South Africa and the Falkland Islands.

KEY WORDS: Antarctica, Dwyka Group, glaciation, Gondwana, Lafonia Group, South Africa, Transantarctic Mountains. 
The Falkland Islands lie in the South Atlantic Ocean, approximately $650 \mathrm{~km}$ east from the Strait of Magellan. Conjecturally Silurian to unequivocally Devonian (and perhaps Lower Carboniferous), fluvial to near-shore, siliciclastic marine strata of the West Falkland Group (Aldiss \& Edwards 1999; Hunter \& Lomas 2003) form the lower part of the islands' sedimentary succession, which rests unconformably on a Proterozoic crystalline basement, the Cape Meredith Complex (Fig. 1). The West Falkland Group is succeeded by the Carboniferous to Permian, mainly marine to deltaic clastic strata of the Lafonia Group (Aldiss \& Edwards 1999; Trewin et al. 2002). Near the base of the Lafonia Group is a glacigenic unit, the Fitzroy Tillite Formation. The whole succession has great similarity to the coeval Palaeozoic successions of South Africa, South America and Antarctica that were deposited contiguously when these present-day continents formed adjacent parts of the Gondwana supercontinent.

The clast assemblage in the Upper Carboniferous Fitzroy Tillite Formation is dominated by quartzite and granitic rock. Rare limestone clasts are present locally and some have proved to be fossiliferous. Archaeocyaths are abundant, varied and locally wellpreserved in clasts of massive, grey and white limestone found in the tillite near Hill Cove, West Falkland (Fig. 1), where fragmentary archaeocyaths also occur in clasts of limestone breccia. A single limestone clast recovered from Port Purvis, also in West Falkland, contains a number of small trilobites in addition to a range of archaeocyaths. In East Falkland, rare clasts of limestone containing a sparse fauna of archaeocyaths have been found in the tillite near Mount Pleasant Airport. Archaeocyaths are exclusively Cambrian (Rozanov \& Debrenne 1974) but the Falkland Islands sedimentary sequence is entirely post-Cambrian and devoid of limestone (Aldiss \& Edwards 1999). Hence the limestone clasts in the tillite are likely to be far-travelled erratics introduced into the Falklands area during the late Carboniferous glaciation that affected wide areas of the Gondwana supercontinent prior to its Mesozoic fragmentation. An Antarctic provenance seems likely (Stone \& Thomson 2005).

In this paper we describe the archaeocyath, radiocyath and trilobite fossils recovered from the limestone clasts in the Fitzroy Tillite Formation and discuss their implications for the wider tectonic and glacial history of Gondwana. We stress that, because the fossils are contained in small erratic clasts within a glacial diamictite, the amount of material available for study is limited. Exploratory thin sections were positioned to make the best use of the clast dimensions and so did not necessarily show the revealed archaeocyaths in ideal circumstances. In all but a few cases, the shapes of the clasts precluded the preparation of additional sections in orientations that would have been ideal to follow-up features noted in 
that original selection. An added constraint in the examination of one clast was the presence of trilobites and spectacular wind-polished natural faces showing archaeocyaths in some detail, features which we are anxious to preserve. Accordingly, the taxonomic detail provided here should be regarded as a preliminary, tentative assessment. We do not claim to present a definitive taxonomic study, which most probably would require the recovery of additional specimens. Rather, this paper seeks to document what is a rare and highly unusual fossil occurrence, to illustrate and describe the variety of species present, and to assess the significance of the fauna in its regional context. All of the specimens described have been deposited at The Natural History Museum, London (NHM), with catalogue numbers NHM PI PO 12074-12110. Representative examples have been deposited in Stanley at the Falkland Islands Museum, and in the Biostratigraphy Collection of the British Geological Survey, Keyworth, Nottingham.

\section{The Fitzroy Tillite Formation}

The Fitzroy Tillite Formation (the Lafonian Tillite in older literature) is the representative in the Falkland Islands of the Upper Carboniferous to Lower Permian glacigenic diamictite that is widespread across the fragments of Gondwana, recording a glacial episode about 290 million years ago (Crowell 1999; Veevers \& Powell 1987). Gondwana began to break up about 200 million years ago and continental fragments were dispersed, each fragment with its own contemporaneous part of the tillite succession: the Dwyka Group in South Africa, the Sauce Grande Formation in Ventania, Argentina, the Whiteout Conglomerate in the Ellsworth Mountains, Antarctica, with distant equivalents also seen in Australia and India. The broad correlation between these different sequences is well established (e.g. Caputo \& Crowell 1985; Matsch \& Ojakangas 1992) but correlations are complicated by the migration of the ice dispersal centres as Gondwana drifted across the southern polar region. Nevertheless, a close correlation between the Fitzroy Tillite Formation and the Dwyka Group tillites is strengthened by the similar age profiles shown by detrital zircons from the matrices of diamictites in those two lithostratigraphical units (Craddock \& Thomas 2011). The peak of glaciation occurred during the latest Carboniferous to earliest Permian interval, with southern Africa and the surrounding regions then affected by several huge, coalescing ice sheets (e.g. Crowell \& Frakes 1972; Caputo \& Crowell 1985). Radiometric ages derived from zircons in thin tuff layers interbedded with the Dwyka Group prove deposition from about 302 Ma to about 290 Ma (Bangert et al. 1999) 
The Fitzroy Tillite Formation of the Falkland Islands (Fig. 1) has been reviewed and formally defined by Aldiss \& Edwards (1999). A comprehensive earlier study by Frakes \& Crowell (1967) related lithological differences between East and West Falkland to different depositional environments, as follows. In the west, a brown, sandy mudstone matrix contains and supports a variety of locally-derived and exotic rock clasts, mostly as small pebbles but ranging up to boulders $7 \mathrm{~m}$ across; included sand bodies may have originated as eskers. This West Falkland tillite is regarded as a terrestrial sub-glacial deposit, although there are no convincing examples of subjacent, striated rock surfaces. In the east, a dark grey and finegrained muddy matrix encloses a sparse assemblage of clasts that tend to be smaller and of a more restricted lithological range than seen in the west; the East Falkland tillite was probably deposited in marine conditions under a floating ice sheet.

Whatever the precise depositional process, the clasts in the Fitzroy Tillite Formation were derived from a wide range of rock types (Halle 1912; Baker 1924; Frakes \& Crowell 1967; Aldiss \& Edwards 1999; Stone \& Thomson 2005), though there is a dominance of siliciclastic sedimentary rock and an important granitic component. Much of the clast assemblage has been loosely ascribed either to the Siluro-Devonian sequence forming the West Falkland Group or to the Proterozoic basement represented by the Cape Meredith Complex (Frakes \& Crowell 1967), although a substantial proportion of the clasts are acknowledged to have no known local source. Quantitative descriptions of the overall clast assemblage are provided by Bellosi \& Jalfin (1984) from the Black Rock area of East Falkland (about 15 km west of Mount Pleasant Airport: Fig. 1), and by Frakes \& Crowell (1967) whose descriptions were consolidated from a range of localities, mostly on East Falkland but including four West Falkland sites. The results reported are similar: Bellosi \& Jalfin list $60 \%$ quartzite, $15 \%$ sandstone and 17\% granitoid; Frakes \& Crowell list 40\% quartzite, 26\% sandstone and 18\% granitoid. Qualitatively assessed differences between the tillite of East and West Falkland, additional to the well-defined facies contrast, include the size range and lithological variety of accessory clasts, both of which appear to be much greater in the west than in the east; and the much higher proportion of red granite and quartzite, relative to white varieties, in the west relative to the east.

The limestone clasts are relatively rare overall but in West Falkland are concentrated at certain localities. In the Hill Cove section, for example, limestone clasts (ranging up to 45 $\mathrm{cm}$ in maximum dimension) were found only at the eastern end; there they are relatively abundant with 22 of the 25 limestone clasts examined in detail proving to contain archaeocyaths. Archaeocyathan limestone clasts appear to be less common in East Falkland 
than in West Falkland. Although limestone is a widespread (though still rare) accessory in the East Falkland tillite only two limestone clasts have been found to contain archaeocyaths out of the 15 examined (ranging up to $15 \mathrm{~cm}$ in maximum dimension). In the West Falkland clasts, the archaeocyaths are commonly visible macroscopically, whereas in the East Falkland clasts the archaeocyaths were discovered only in thin section. The apparent concentration of archaeocyathan limestone clasts at a few localities in West Falkland, rather than their being randomly distributed, is a feature that may have broad stratigraphical and palaeogeographical implications but these are beyond assessment by the currently available, sparse database.

Microbial material, Epiphyton or possibly Gordonophyton is present in most of the archaeocyathan limestone clasts from both West and East Falkland. Possible stromatolite fragments are present in several of the clasts from the West. From East Falkland additional, though rather tentative biogenic traces are ooids in a clast collected at Mount Pleasant (BGS specimen LX1003); the ooids may have had an algal component to their formation (Davis et al. 1978). Frakes \& Crowell (1967) also reported ‘oolitic limestone’ as a clast lithology but did not specify where it occurred.

\section{The archaeocyaths}

The first archaeocyaths to be discovered in the South Atlantic region were contained in a limestone pebble, an ice-rafted erratic, dredged from the bed of the Weddell Sea during the Scottish National Antarctic Expedition (1902-1904). The specimen was not submitted to W T Gordon for description until 1913 and it was another seven years before his account was eventually published in Transactions of the Royal Society of Edinburgh (Gordon 1920). In the meantime, during Shackleton’s British Antarctic Expedition (1907-1909), archaeocyaths had been discovered on the Ross Sea side of Antarctica, in the Transantarctic Mountains, leading to the first published record from that continent (Taylor 1914). The more extensive archaeocyath fauna from Australia had also become better known (e.g. Taylor 1910) and Gordon commented on the striking similarities between it and the Antarctic fauna.

Since Gordon's (1920) account was published, the Australian and Antarctic records have been much extended. In Antarctica, Early Cambrian archaeocyaths occur in situ in limestone (and in clasts within associated, locally-derived conglomerate) in the Transantarctic Mountains (e.g. Debrenne \& Kruse 1986, 1989), the Shackleton Range (Buggisch \& HenjesKunst 1999), and the Argentina Range (Konyushkov \& Shulyatin 1980). Allochthonous occurrences include those in clasts within the Permo-Carboniferous Whiteout Conglomerate (the local representative of the Gondwanan tillite) in the Ellsworth Mountains (Debrenne 
1992), in clasts contained in Palaeogene diamictite in the South Shetland Islands (Wrona \& Zhuravlev 1996), and widely in loose material in moraine (e.g. Hill 1964a, 1964b, 1965; Morycowa et al. 1982). Southern Australia has yielded very diverse Early Cambrian archaeocyath faunas (e.g. Debrenne 1969; Gravestock 1984; Kruse 1978, 1982; Zhuravlev \& Gravestock 1994). Whilst many Australian taxa have also been found in Antarctica, most have yet to be recorded elsewhere in the Southern Hemisphere. Archaeocyaths have been found in sub-Saharan Africa only in clasts contained in Dwyka Group tillites (Cooper \& Oosthuizen 1974; Debrenne 1975; Oosthuizen 1981). Until very recently none had been recorded in South America, but since the first Falklands discovery archaeocyath-bearing limestone clasts have been found in two separate situations in Argentina: a Cambrian conglomerate (González et al. 2011) and the Upper Carboniferous Sauce Grande Formation tillite (González et al. 2012).

From the West Falkland tillite, more than 20 archaeocyath-bearing limestone clasts have been collected in situ at Fox Point, to the east of Hill Cove, whilst a particularly striking clast containing both archaeocyaths and small trilobites was found loose but resting on exposed tillite bedrock at Gladstone Bay, an inlet at the western end of Port Purvis (Fig. 1). The wind-abraded surfaces of the Port Purvis specimen reveal the archaeocyaths in spectacular detail (Figure 2: cf. Stone \& Rushton 2003; Stone \& Thomson 2005). From the East Falkland tillite, two limestone clasts with a sparse fauna of small archaeocyaths were collected in situ at Frying Pan Quarry, near Mount Pleasant Airport. Descriptions are based on thin sections (Fig. 3) prepared from all of the clasts found at Hill Cove and Frying Pan Quarry. For the exceptional Port Purvis clast, a thin section was prepared from a small flake of limestone removed during development of the trilobites. No other sections have been prepared from this clast in order to preserve both those trilobites and the archaeocyaths seen in detail on its natural faces.

In their review of the archaeocyath faunas of Antarctica, Debrenne \& Kruse (1989) noted that at least 43 Early Cambrian archaeocyaths had been determined at the species level in Antarctica, mostly from the Transantarctic Mountains: 15 of those are present in South Australia within in situ strata, whilst 9 have been recorded from erratic clasts within the Dwyka Tillite of South Africa. None of the 250 species recorded from Gondwana is known from other continents, although 32 of the 43 known Gondwanan genera also occur in the Northern Hemisphere. Debrenne \& Kruse also confirmed (op. cit. p. 24) that the faunas from South Africa, Antarctica and Australia were all closely related and constituted a Gondwana faunal province. 
All the South African material comes from clasts within the tillites of the Dwyka Group, the stratigraphical correlative of the Fitzroy Tillite Formation in the Falkland Islands. Debrenne \& Kruse (1989) reiterated Cooper \& Oosthuizen's (1974) conclusion that the South African material comprised erratics derived from Antarctica during Permo-Carboniferous glaciation. Where preservation in the Falklands' material is sufficiently detailed to allow comparison, similarities are with Antarctic archaeocyaths in particular, and hence also with the exotic South African examples, which were themselves derived from Antarctica. Taxa identified from the Falkland Islands are listed in Table 1, with detail provided below in the systematic palaeontology section. We caution that since the faunal list is derived from an assemblage of clasts in a glacigenic diamictite, it may well contain taxa indicative of more than one stratigraphical level.

The vast majority of archaeocyath faunas world-wide are of Early Cambrian age, with only two younger occurrences from the southern hinterland of the Weddell Sea, Antarctica. Both are single-species occurrences and probably represent refuge faunas: one is from a storm deposit in the Nelson Formation (mid-late Middle Cambrian) in the Neptune Range (Wood et al. 1992) and the second is from the Minaret Formation of the Ellsworth Mountains (Debrenne et al. 1984; Debrenne 1992), firmly dated as the Idamean Stage of the Furongian (Late Cambrian) . The stratigraphy of Antarctic archaeocyaths in general is poorly understood, not least because many occurrences are allochthonous, with specimens collected from scree, moraine or conglomerate. As stressed above for the clasts from the Fitzroy Tillite Formation, the allochthonous material - for example the collection from moraine at the Whichaway Nunataks (Hill 1965) or that from pebbles in a Cambrian conglomerate in the Shackleton Range (Buggisch \& Henjes-Kunst 1999) - may not all represent the same stratigraphical level. Of course, the same is true for the collection of erratic clasts contained in the Dwyka Group tillites. That said, it would seem unlikely that an assemblage of clasts in any one locality, whether 'recent' or ancient glacial erratics, would have come from more than one source region. Variations in the matrices of the clasts from any one locality, as seen in the Falklands assemblage, can be regarded as representing a range of facies from a single stratigraphical association. Despite these difficulties there is a consensus that the Antarctic faunas from the Transantarctic Mountains support a Botomian (Botoman is preferred by some authors) age (Debrenne \& Kruse 1989). This spans, approximately, the boundary between stages 3 and 4 of Cambrian Series 2 in the proposed chronostratigraphical subdivision of the Cambrian System (Babcock et al. 2005). 


\section{The trilobites}

There proved to be several small trilobites in the limestone clast from Port Purvis that also featured the strikingly exposed archaeocyaths on its wind-abraded surfaces (Fig. 2). This exceptional clast has not been cut and the account of the trilobites presented here is based on the few examples that could be accessed on the one face of the block where archaeocyaths were not abundant. Extraction and development of the trilobites proved difficult, but several cranidial fragments, a librigena and two pygidia were found. Some of the cranidia are comparable with the Early Cambrian genus Yorkella, though they do not resemble described species very closely. The librigena is doubtfully associated with this taxon. Two further taxa are represented by small cranidia that are apparently referable to the family Namanoiidae, which occurs typically in the Botomian to Toyonian of Siberia. One is similar to the Siberian genus Chondrinouyina, whilst the other is comparable to a juvenile form of Namanoia. The larger of the two pygidia is multi-segmented and shows some similarity to the trilobite Edelsteinaspis, which is known from the Early to Middle Cambrian strata in Siberia, but the smaller pygidium is undetermined.

Despite the uncertainties of identification the most likely age for the trilobites seems to lie within Stage 4, Cambrian Series 2 (Babcock et al. 2005), probably towards the lower part of the stage. This would overlap with the Botomian age assigned to the archaeocyath faunas from the Transantarctic Mountains, but it should be stressed that only one of the Falkland Islands clasts (PS 218) contains both determined archaeocyaths and trilobites and so is the only example definitively constrained by the overlap.

\section{The regional setting}

In reconstructions of Gondwana the Falklands microplate is generally rotated through almost $180^{\circ}$ and placed off the east coast of South Africa (e.g. Adie 1952; Marshall 1994; Storey et al. 1999; Trewin et al. 2002) in proximity to East Antarctica and the Ellsworth Mountains microplate. Though it must be stressed that this does not represent a unanimous view, there is a consensus that the Palaeozoic sedimentary sequence preserved in the Falkland Islands is a correlative of those present on the once-contiguous parts of the Gondwana supercontinent now fragmented into South America, Africa and Antarctica. Particularly close stratigraphical similarities are seen between the Falkland Islands and the Cape Fold Belt and Karoo Basin of South Africa (e.g. Aldiss \& Edwards 1999; Trewin et al. 2002; Hunter \& Lomas 2003) with the Fitzroy Tillite Formation (Falkland Islands) being equivalent to tillites within the Dwyka Group (South Africa). 
Stone \& Thomson (2005) argued that the archaeocyathan limestone clasts from the Fitzroy Tillite Formation were originally derived, within a Gondwanan context, from what is now Antarctica. In East Antarctica, Early Cambrian archaeocyathan limestone is present in situ at several localities in the Transantarctic Mountains (e.g. Hill 1964a; Laird \& Bradshaw 1982; Debrenne \& Kruse 1986, 1989), as pebbles in Cambrian conglomerate from the Shackleton Range (Buggisch \& Henjes-Kunst 1999) and as loose material in recent moraines (e.g. Hill 1964b, 1965). The specimens collected at Whichaway Nunataks (during the 1957-58 Trans-Antarctic Expedition) are now housed in The Natural History Museum, London, and show a macroscopic similarity between their limestone lithology and that of some white limestone clasts from Hill Cove, West Falkland.

A close analogy to the Falkland Islands situation is seen in Dwyka Group tillites from South Africa, where rare archaeocyathan limestone clasts have also been recorded and Antarctica proposed as the most likely provenance since archaeocyaths are otherwise unknown in the region (Cooper \& Oosthuizen 1974; Debrenne 1975; Oosthuizen 1981). A similar origin has been accorded to archaeocyaths recently discovered in the Argentine representative of the Late Carboniferous Gondwana tillite, the Sauce Grande Formation (González et al. 2012). Although there are no substantiated reports of in situ archaeocyaths from Cambrian strata in Argentina, archaeocyath-bearing limestone clasts have recently been discovered in a Cambrian conglomerate (González et al. 2011) which invites comparison with some of the Antarctic occurrences. These regional comparisons become important in an assessment of the role of a Falklands microplate in the break-up of Gondwana.

Frakes \& Crowell (1967) deduced a broadly west to east ice flow (in present-day coordinates) across the Falkland Islands, a conclusion based on glacial facies distribution and the west to east decrease in the average and maximum clast sizes. Accordingly, a South American provenance was tentatively proposed for the Fitzroy Tillite despite references elsewhere in their paper to the palaeogeographical reconstruction of Adie (1952) that placed the Falklands adjacent to South Africa. Du Toit (1937) had realized that the geological features of the Falkland Islands, in their present position, were considerably out of line with his pioneering pre-Atlantic reconstruction of Gondwana. Adie built on Du Toit's ideas (Stone \& Rushton 2012) to propose that, as the Atlantic Ocean opened, the islands had experienced a rotation of up to $180^{\circ}$ from an original position off the south-east coast of Cape Province. Subsequent plate tectonic reconstructions (e.g. Marshall 1994; Storey et al. 1999) have concurred, regarding the Falklands as one of several microplates occupying space between the major juxtaposed continental masses of Africa and East Antarctica. 
The position of the Falklands in a typical 'rotational' reconstruction is illustrated in Figure 4a. Superimposed are the recognized ice-flow directions from the Fitzroy Tillite Formation (Falklands) and the Dwyka Group (South Africa): the Fitzroy Tillite Formation flow is the west to east direction deduced by Frakes \& Crowell (1967) rotated through about $180^{\circ}$; the Dwyka Group flow is taken from a recent summary of evidence by Moore \& Moore (2004); cf. González et al. (2012, figure 7). There is a general alignment of ice flow azimuths that links the tillites of the Falklands and the southern Cape Province with a source region in the Transantarctic Mountains. However, a note of caution is justified. The evidence from the Falkland Islands for the direction of ice-flow there is relatively weak, based as it is on facies interpretations, whilst the ice flow patterns from South Africa are complex and probably polyphase (Crowell \& Frakes 1972; Caputo \& Crowell 1985; Visser et al. 1986).

In general terms, the clast population of the Dwyka Group tillites, like that of the Fitzroy Tillite Formation, is dominated by quartzite and granitic rocks. However, the distribution of archaeocyathan limestone clasts provides a strong case for the close association of the tillite in the Falklands with that in the eastern Cape Province of South Africa, a situation compatible with a 'rotational' reconstruction of the Falklands position in Gondwana. The archaeocyath-bearing clasts described from the Dwyka Group tillites (Cooper \& Oosthuizen 1974; Debrenne 1975; Oosthuizen 1981; Visser et al. 1986) all occur in its outcrop in the eastern Cape Province. A provenance in the Transantarctic Mountains could, in a rotational reconstruction, readily supply both the eastern Cape and the Falklands via an ice flow from the 'east' (Fig. 4a). Elsewhere in the Dwyka Group, in the western Cape Province, stromatolitic limestone clasts derived from the Ghaap Plateau were introduced by ice flow from the north-east, the Transvaal ice sheet (Visser et al. 1986). Stromatolitic limestone clasts of this kind, devoid of archaeocyaths, have not been found in the Fitzroy Tillite Formation.

The rotational model for the break-out from Gondwana of the Falklands microplate is derived almost exclusively from onshore geological evidence; from the offshore geological dataset there is no requirement to rotate such a microplate when reconstructing the preAtlantic continental relationships. A typical result from that perspective (Richards et al. 1996) is shown in Figure 4b, with the ice flow directions again superimposed. Taken at face value, the Falklands data, as noted by Frakes \& Crowell (1967) would seem to require derivation of the Fitzroy Tillite from South America. If true, there would need to have been a source of archaeocyathan limestone in the Patagonia area that has been entirely removed by erosion or covered by younger strata. This is not impossible, though unlikely. The archaeocyath-bearing limestone clasts recently reported from eastern Argentina (Fig. 4) by González et al. (2011, 
2012), from both a Cambrian conglomerate (El Jagüelito Formation) in the Sierra Grande region, and the Upper Carboniferous tillite (Sauce Grande Formation) in Ventania, may have had a local source although González et al. identify the Transantarctic Mountains as a possible provenance for both occurrences. Overall, carbonate clasts form about $6 \%$ of the assemblage in the Sauce Grande Formation (Amos \& Gamundi 1981) although only a few carry archaeocyaths; otherwise, the clast population - 53\% quartzite, 19\% granite, $8 \%$ vein quartz, 6\% volcanic rocks, 4\% gneiss (Amos \& Gamundi 1981) - is broadly similar to that of the Fitzroy Tillite Formation and the Dwyka Group tillites. In general, Cambrian continental reconstructions militate against a South American source of archaeocyathan limestone by placing all but the extreme south of that continent (and all of southern Africa) farther south than the equatorial latitudes, between $30^{\circ}$ north and south, to which Cambrian Gondwana archaeocyaths were restricted (e.g. Courjault-Radé et al. 1992; Torsvik \& Cocks 2011).

Despite the new evidence from South America, we still consider it most likely that the archaeocyathan limestone clasts in the Fitzroy Tillite Formation and the Dwyka Group tillites were sourced from the Transantarctic Mountains. Indeed, the faunal similarities between the limestone of the Transantarctic Mountains and the clasts in the Fitzroy Tillite Formation are strengthened further by the palaeontological data presented in this paper. Accordingly, we see no reason to revise our previous conclusion (Stone \& Thomson 2005) that the presence of archaeocyathan limestone in the Fitzroy Tillite Formation is strongly supportive of a Gondwana reconstruction, after Adie (1952), which rotates the Falklands into a position adjacent to the Eastern Cape Province of South Africa.

An additional point of interest deriving from the distribution of the archaeocyathan limestone clasts is its implications for the extent of the Permo-Carboniferous ice sheet. Whilst a large ice sheet extending out from the Pole to cover much of southern Gondwana is accepted in most palaeogeographical proposals (e.g. Scotese et al. 1999), it has been challenged following recent work in the Transantarctic Mountains themselves. There, Isbell et al. (2003, 2008a) have reported evidence for an absence of ice cover during the Carboniferous, with Permian sedimentation under ice-marginal, periglacial and/or glaciomarine conditions. Far-travelled erratics, derived from the Transantarctic Mountains and deposited in a terrestrial glacial environment late in the Carboniferous, are very difficult to reconcile with the evidence presented by Isbell et al. Resolution of this apparent impasse will probably require further investigations in all relevant areas. 


\section{Conclusions}

The discovery in the Fitzroy Tillite Formation, Falkland Islands, of Cambrian limestone clasts containing an archaeocyath-trilobite fauna bears significantly on several aspects of the regional geology.

\subsection{Cambrian palaeobiology}

Archaeocyaths are not common in the Southern Hemisphere, with in situ faunas described only from Antarctica and Australia. The archaeocyaths found in the limestone clasts from the Fitzroy Tillite Formation are undoubtedly of Australo-Antarctic affinity; though less definite, the trilobite Yorkella? can be similarly interpreted. Differences between the archaeocyath assemblages found in different clasts from the Fitzroy Tillite, and in different parts of its outcrop, can probably be ascribed to facies variations in the original Cambrian reef environment rather than to different stratigraphical provenances, although the latter cannot be ruled out.

In view of the Australo-Antarctic affinity of the archaeocyaths, the presence of trilobites that are comparable with Edelsteinaspis and namanoiid taxa, which are known from shallow inner-shelf basins on the Siberian Platform (Pegel 2000), is unexpected, particularly because Early Cambrian trilobites are recognised as provincially restricted (Palmer 1973, 1998). Nevertheless, faunal connections between Australia, Antarctica and Siberia are documented (Palmer \& Rowell 1995, p. 4). This may partly be a reflection of the enormous amount of work that has been done on the highly fossiliferous Cambrian rocks of the Siberian Platform, a taste of which may be sampled in Varlamov et al. (2008). Palaeogeographical reconstructions for the Cambrian (Torsvik et al. 1996) place the Siberian craton just south of the palaeo-equator but on the opposite side of the world from Australia and Antarctica. However, Australia and Antarctica were also placed near the equator and at similar latitudes to Siberia, so it is possible to envisage shelf-dwelling trilobites migrating along the subequatorial shelf seas that surrounded the great southern continent of Gondwana. Indeed, the presence of the distinctive dinesid trilobites in all these regions (Dinesus in Australia and Siberia, Erbia and its relatives in Siberia and Antarctica) is evidence that some such migrations did take place. 


\subsection{Extent of the Permo-Carboniferous ice-sheet}

The Falklands archaeocyathan limestone clasts are mostly found in the terrestrial glacigenic lithofacies of West Falkland, with only a few recovered from the glaciomarine lithofacies of East Falkland. Assuming a source in the Transantarctic Mountains, this would require that during the Late Carboniferous the Gondwana ice sheet flowed from the contemporaneous polar region to almost $60^{\circ}$ south, at least, before becoming glaciomarine. Whilst a large ice sheet with these dimensions is accepted in many palaeogeographical proposals (e.g. Scotese et al. 1999), it is not supported by recent work in the Transantarctic Mountains themselves (Isbell et al. 2003, 2008a). Further work on the Falklands clasts may help resolve this apparent contradiction, which is compounded by the South African record of multiple ice dispersal centres and consequential likelihood of clast re-working (Crowell \& Frakes 1972; Caputo \& Crowell 1985; Visser et al. 1986; Isbell et al. 2008b).

\subsection{Gondwana reconstructions}

Reconstructions of Gondwana that restore a coincidence of ice flow patterns between the Falkland Islands and South Africa (Fig. 4a) are supported by the occurrence of the unusual archaeocyathan limestone clasts in both areas. In particular, the distribution of these distinctive clasts associates the Falkland Islands with the Eastern Cape Province, and so adds further credibility to those reconstructions that place the Falklands microplate in a position off the south-east coast of South Africa prior to its substantial rotation during the break-up of Gondwana (cf. Adie 1952; Marshall 1994; Storey et al. 1999; Trewin et al. 2002).

\section{Systematic Palaeontology}

\subsection{Archaeocyaths ... (M.R.A. Thomson)}

Figures 5-9. Individual illustrations are identified by numbers prefixed with the letter P, which relate to scanned images held in the collection of the British Geological Survey. The correlations of these numbers with the NHM catalogue, and the inter-relationship of the illustrations established by the preliminary working numbers, are listed in Table 2. As far as preservation of the material will allow, the systematic arrangement of species follows that set out in Debrenne et al. (2002). For the sake of brevity, references to the authorities for the described taxa are not included here but may be found in the comprehensive bibliography within that work. 
Class Archaeocyatha Bornemann, 1884

Order Monocyathida Okulitch, 1935

Family Tumuliolynthidae Rozanov, 1966

Genus Tumuliolynthus Zhuravleva, 1963

Tumuliolynthus irregularis (R. Bedford \& W. R. Bedford, 1934)

Figs. 3a, 6c

The species is represented by one narrow longitudinal section (thin section P601012; Fig. 6c) and a small sub-circular transverse section (P 537735; near centre of Fig. 3a) from singlewalled cups. The longitudinal section is incomplete but measures approximately $9 \mathrm{~mm}$ long with a maximum diameter of $2.6 \mathrm{~mm}$; the transverse section is $1.2 \mathrm{~mm}$ across. The wall of the cup is variable in thickness (up to $0.14 \mathrm{~mm}$ ) and pierced by irregularly arranged pores up to $0.2 \mathrm{~mm}$ diameter, issuing from raised tumuli. The longitudinal section intersects three tumuli with pores and the basal swellings of at least two more tumuli; on the transverse section there are three pores.

The simple construction and irregular shape recall those seen in specimens of Tumuliolynthus irregularis from King George Island (Wrona \& Zhuravlev 1996, pl. 3,1) and from New South Wales, Australia (Kruse 1982, text-figs 6, 8A-E, see especially 8A).

Family Favilynthidae Debrenne, 1989

Genus Favilynthus Debrenne, 1974

Favilynthus cf. contractus (Hill, 1965)

Figs $5 \mathrm{a}-\mathrm{C}$

The two best thin sections (P601022 and P601023) intersect fragments of three large, single-walled cups, reaching $35 \mathrm{~mm}$ or more in diameter. The wall (Fig. 5a, b) is proportionally thin in relation to the overall size of the cup with a maximum observed thickness of $3 \mathrm{~mm}$. Cup shape is irregular, one specimen having a deep fold in the wall (Fig 5a). The wall is pierced by oblique canals (up to $1 \mathrm{~mm}$ in diameter) set approximately $1 \mathrm{~mm}$ apart. Sections through thicker parts of the wall locally cut two or more canals in one radial line, suggesting that the canals are proportionally long and markedly oblique; dumb-bell shaped 'pore' sections indicate that some canals anastamose. The highly irregular profiles of the inner and outer surfaces of the wall suggest that the canals open inwards and outwards as simple tubes without any coverings or modifications. 
A longitudinal section of the basal conical portion of a single-walled cup with simple pore openings only (Fig. 5c) probably belongs to the same species.

The transverse sections show good general agreement with those described and illustrated as Monocyathus contractus (Hill 1965, especially pl. 1, figs 1a-d) from erratics in a moraine at Whichaway Nunataks, Antarctica, except that the structure of the present examples is perhaps a little coarser and more irregular. The species is now placed within the genus Favilynthus (Debrenne et al., 1990).

Order Ajacicyathida R. Bedford \& J. Bedford, 1939

Suborder Ajacicyathina R. Bedford \& J. Bedford, 1939

Superfamily Bronchocyathoidea R. Bedford \& J. Bedford, 1936

Family Bronchocyathidae R. Bedford \& J. Bedford, 1936

Genus Thalamocyathus Gordon, 1920

Two sections of small cups from clasts PS304-3 and 304-7 share the general features of Thalamocyathus Gordon (1920) but show slight differences that may place each in a different species. However, the literature is confusing as to the precise limits of the two most commonly described species, T. trachealis (Taylor, 1910) and T. tectus Debrenne, 1973, and Wrona \& Zhuravlev (1996, p. 22) even suggested that there may be a continuum of variability between the two.

\section{Thalamocyathus trachealis (Taylor, 1910)}

Fig. 6c

A partly oblique transverse section (Fig. 6c) from clast P601012 is about $3.6 \mathrm{~mm}$ across (cup diameter) by $7 \mathrm{~mm}$ long; the intervallum is about $1 \mathrm{~mm}$ across. On the more oblique cut of the section, the outer wall is finely porous, with three to four closely adjacent alternating rows of rounded polygonal pores per intersept. The pores are covered with planar diaphragms. In the section available, there are 40 full septa and five others inserted from the outer wall; they are thin and variably porous. Each intersept has a single large opening into the central cavity. The inner wall consists of v-shaped annuli which are thickened at their proximal rims and taper finely toward their distal margins. On some cross-sections of the annuli (see especially top left of Fig. 6c) it is possible to see the trace of a carina on the convex face. Traces of several thin pectinate tabulae are present. 
The specimen compares well with specimens assigned to Thalamocyathus trachealis (Taylor 1910), by Hill (1965, p. 94, pl. VII, figs 2a-e) from Whichaway Nunataks, Antarctica, from King George Island by Wrona \& Zhuravlev (1996, pl. 3, fig.3), and with specimens from Yorke Peninsula, Australia (Zhuravlev \& Gravestock 1994, especially fig. 8A). The specimens from Whichaway Nunataks were later placed in a new species, T. tectus, by Debrenne (1973). However, similarities between specimens of T. tectus, illustrated by Debrenne (1975, fig.1b and c) from erratic blocks within the Dwyka Tillite of South Africa, are less certain, particularly with respect to the reduced concentration of pores in the outer wall.

\section{Thalamocyathus sp.}

Fig. 6d

An almost perfectly circular transverse section of a cup from sample PS304-7c is $5 \mathrm{~mm}$ in diameter and has an intervallum between 1.1 and $1.2 \mathrm{~mm}$ across. There are 43 full septa and one inserted septum. Fragments of tabulae are markedly pectinate (right-hand side of Fig. 6d). It differs from the specimen assigned to T. trachealis, above, in several details: there appear to be no more than three rows of pores per intersept in the outer wall, the septa are less porous, and the annuli appear to be more robustly constructed. Whether or not these differences are sufficient to justify assignment to a separate species is debatable. However, the more robust construction of the annuli is reminiscent of that seen in Thalamocyathus ex gr. trachealis, illustrated by Wrona \& Zhuravlev (1996, pl. 3.7) from erratic boulders in glacial and glaciomarine sedimentary rocks on eastern King George Island.

Family Ethmocyathidae Debrenne, 1969

Genus Ethmocyathus R. Bedford \& W. R. Bedford, 1934

Ethmocyathus lineatus R. Bedford \& W. R. Bedford, 1934

Fig. 6e, $\mathrm{f}$

The species is represented by two sections from clast PS304-8, one transverse (P601024, Fig. 6e) and one sub-longitudinal (P601023, Fig. 6f). The transverse section is slightly oblique and the maximum and minimum diameters of the section are 9.4 and $5.6 \mathrm{~mm}$ respectively; the width of the intervallum is about $2 \mathrm{~mm}$. The outer wall is thin and simply porous, with three or possibly four rows of pores per intersept. Septa are aporose to sparsely porous and relatively closely spaced (49 are present) forming proportionally narrow 
intersepts. There are faint traces of a thin pectinate tabulum on the transverse section (Fig. 6e, left). On the inner wall, there is one large rounded to polygonal canal opening per intersept, crossed by a series of one to four v-shaped annuli per opening (Fig. 6f).

The sections compare favourably with examples of Ethmocyathus lineatus, illustrated by Debrenne \& Kruse (1986, fig. 11) from the Holyoake Range of the Transantarctic Mountains, the variable number of annuli per internal pore opening, as opposed to three in the diagnosis of E. lineatus (Debrenne \& Kruse 1986, p. 246) is regarded as a trivial difference. The species is also known from the Ajax Limestone of South Australia (Debrenne 1969, p. 323).

Superfamily Ethmophylloidea Okulitch, 1937

Family Kijacyathidae Zhuravleva, 1964

Genus Flexanulus Debrenne, 1975

Flexanulus oosthuizeni Debrenne, 1975

Fig. $5 g$

A small (4.4 mm maximum diameter) slightly oblique section in slide P601013 (Fig. 5g) bears a striking resemblance to Debrenne's (1975, fig. 3a) illustration of Flexanulus oosthuizeni from the Dwyka Tillite of South Africa. The present specimen is about half the size of the South African example, but shows the same arrangement of annuli with deep flexed sides in the central cavity. Preservation of the outer wall is only poor to moderate and, together with the lack of any longitudinal sections, makes it impossible to prove the special construction described and illustrated in detail by Debrenne (1975, fig. 2). However, there appear to be two pores per intercept, most of which in the transverse section appear as roughly oval and elongated parallel to the wall, comparable to those in the illustrated South African specimen, i.e. they appear to represent sections through steeply inclined tubes. Septa seem to be only sporadically perforate; twenty full septa are present, with another four or five short ones being inserted from the outer wall. A second, less well preserved and smaller example on slide P601106 (clast PS304-5) has the same flexed annuli on the inner wall and also shows the presence of a pectinate tabulum.

Originally known only from South Africa, Debrenne \& Kruse (1989, fig. 3D) reported they had found a representative of Flexanulus cf. oosthuizeni in a collection from the Beardmore Glacier area, Antarctica, previously identified by Hill (1964b) as Thalamocyathus trachealis (Taylor), and now it is known also from the Falkland Islands. 
Suborder Erismacoscinina Debrenne, Rozanov \& A. Zhuravlev, 1990

Superfamily Salairocyathoidea Zhuravleva, 1956

Family Asterocyathidae Vologdin, 1956

Genus Erismacoscinus Debrenne, 1958

?Erismacoscinus sp.

Fig. 7c

A slightly oblique cross-section of a cup from clast PS304-3 (Fig. 7c centre right) has a maximum diameter of $7.8 \mathrm{~mm}$ and a minimum diameter of $4.7 \mathrm{~mm}$; the intervallar width varies between 0.9 and $1.4 \mathrm{~mm}$. Secondary thickening on both walls obscures much of the detail but the skeletal elements are thin and both walls are simply porous. It is difficult to discern the arrangement of the pores but it appears that there are two vertical rows per intersept on the outer wall, and two or three per intersept on the inner wall in a mesh-like arrangement. Septa and tabulae are porous. The general features of this specimen resemble those of the genus Erismacoscinus, but the material is too poor to be more precise.

Superfamily Polycoscinoidea Debrenne, 1964

Family Polycoscinidae Debrenne, 1964

Genus Polycoscinus R. Bedford \& J. Bedford, 1937

Polycoscinus scutatus? (Hill, 1965)

Fig. 8a, b

Although preserved in a strongly recrystallised matrix, some fragmentary specimens in sections P601015 and P601016 from clast PS304-5 (Fig. 8a and b) show features reminiscent of specimens previously referred to the genus Erugatocyathus Debrenne, now regarded as junior synonym of Polycoscinus R. Bedford \& J. Bedford. Much of the outer wall is missing or incomplete but, where preserved, it is relatively thin with two or three rows of pores per intercept. Small peg-like protrusions from the wall between the pores support a microporous sheath (Fig. 8b). Septa are probably completely porous, with some pores obscured by secondary thickening, and thicken toward the inner wall. The inner wall is thicker than the outer wall and has proportionally large pores; there are two rows per intersept. Each pore is covered with a cupped bract bearing a spine projecting into the internal cavity. Tabulae are finely porous. 
Despite their deficient preservation, in general the features of these specimens recall those of Erugatocyathus scutatus (Hill 1965) from moraines at Whichaway Nunataks (= Torgaschinocyathus scutatus Hill 1965, p. 104-105, pl. VIII, figs 1-3) and from Cenozoic tillites on eastern King George Island, South Shetland Islands (Wrona \& Zhuravlev 1996, p. 25, pl. 5, fig. 7). In particular, although not easily seen on published illustrations, the details of the peg-like protrusions on the outer wall and the internal pores covered by cupped bracts, each with a single prominent spine, accord well with Hill's (1965) description. The species has also been described from South Australia (Zhuravlev \& Gravestock 1994, p. 27, fig. 9B).

\section{Polycoscinus cf. papillatus (Bedford \& Bedford, 1934)}

Fig. 7e, $\mathrm{f}$

A transverse section and a longitudinal section of a moderately elongate conical cup on slide P601025 from clast PS304-8 may or may not represent individuals of the same species joined by exothecal tissue (Fig.7e). The transverse section (Fig. 7f) is the best preserved. It is subquadrate, with a maximum diameter of $9.4 \mathrm{~mm}$, whilst the width of the intervallum varies between 1.25 and $2.3 \mathrm{~mm}$. The outer wall is finely porous. However, because of secondary thickening, the number of pores per intersept is not always clear; there generally appear to be four. Septa are porous and thicken slightly at their junction with the outer wall. Circular pores on the inner wall end in cupped bracts; there are three per intersept. A few porous tabulae are present.

Whilst the exothecal overgrowth makes it impossible to determine the presence or absence of any external microporal sheath and, although preservation is only moderate, the general features of these specimens otherwise agree with those of Erugatocyathus Debrenne, a junior synonym of Polycoscinus R. Bedford \& J. Bedford. In most described sectioned examples, the pores of the internal wall are partially screened by cupped bracts,

Because of poor preservation, the affinity of the longitudinal section (Fig. 7e), is difficult to assess. There is general similarity between the main skeletal elements of the two individuals, but the pores on the internal wall terminate in rounded papillose extensions, not unlike the preservation of the bracts seen in the upper part of the transverse section in Fig. 7f. The presence of papillae, is well seen in three-dimensional material from Australia (Polycoscinus papillatus (Bedford \& Bedford) in Debrenne 1973, pl. II, fig. 7, pl. III, fig. 3), and is not unlike those seen in the present material. 
Superfamily Porocoscinoidea Debrenne, 1964

Family Porocoscinidae Debrenne, 1964

? Porocoscinidae Genus indet.

Fig. $7 d$

A slightly oblique transverse section of an incomplete cup in slide P537735 (Fig. 7d) shows a number of details of the outer and inner walls which apparently set it apart from other specimens in the same slide, yet its identity has proved elusive. The cup had an estimated diameter of about $6.5 \mathrm{~mm}$ and an intervallar width of $1.2 \mathrm{~mm}$. The outer wall is thin, with four or five offset rows of non-communicating s-shaped canals, possibly protected by bracts. Septa are thin and porous; tabulae are numerous and finely porous. The structure of the inner wall is indistinct but appears to be characterized by four rows of pores or canals per intersept; each has a distinctive square cross section.

Without better-preserved material it is not possible to place this species with any confidence, but the structure of the outer and inner wall with its square section canals recall those of some Porocoscinidae, notably Porocoscinus Debrenne, 1964, or perhaps Flexicyathus Kruse, 1978.

Order Archaeocyathida Okulitch, 1935

Suborder Archaeocyathina Okulitch, 1935

Superfamily Archaeocyathoidea Hinde, 1889

Family Archaeopharetridae R. Bedford \& W.R. Bedford, 1936

Genus Protopharetra Bornemann, 1884

“Protopharetra” spp.

Fig. 8c-e

Several sections (P537735 and P601013, clast PS303-3; P601015, clast PS304-5; P601024, P601025, and P601026, clast PS304-8) all contain irregular, elongate to subtriangular fragments made up of vesicles and branching 'platelets' or 'rods'. Their exact taxonomic status is uncertain but they are described here under a convenience name, for completeness. Two types, which differ essentially in the proportion and density of the 'platelets' or 'rods' (cf. Fig. 8c with Fig 8d and e), may or may not represent different taxa.

In general, the lack of any clear or organised shape makes most of the fragments difficult to interpret, but the best (a 'platelet'- and 'rod'-rich form in slide P601014, Fig. 8c) 
shows a group of individuals from a colony. Cups seem to be roughly cylindrical in form with an imperforate outer wall. The intervallum is filled with irregularly arranged semiopaque platelets and rods, separated by thin vesicles forming irregular bubble-like structures. The larger (right hand) cup is seen in tangential longitudinal section; it is about $18 \mathrm{~mm}$ long and $5 \mathrm{~mm}$ wide, its apertural end is corroded but there appears to be a small cavity a little over $1 \mathrm{~mm}$ wide, which may represent the central cavity of the cup. This is better seen on the oblique transverse section (to the left) where the cup diameter is about $4 \mathrm{~mm}$ and the central cavity about $0.8 \mathrm{~mm}$ across. The two cups, plus parts of two others are joined by an irregular framework of 'rods', of similar material to that of the external wall and the internal 'platelets' and 'rods'.

In general appearance the fragments with fewer 'platelets' and 'rods' (Fig. 8d and e) resemble some of the material included by Gordon (1920) in his Archaeocyathus pauciseptatus (= Protopharetra pauciseptata; Debrenne \& Kruse 1989, p. 26; see especially Gordon 1920, pl. VI, fig. 64, and also Debrenne 1975, fig. 9b). Other specimens may be more akin to P. densa Bornemann from the Dwyka Tillite of South Africa (Debrenne 1975, fig. 9a), later transferred to Archaeocyathus by Debrenne \& Kruse, 1989, p. 24.

Genus Spirocyathella Vologdin, 1939

Spirocyathella cf. cooperi (Debrenne, 1975)

Figs 8g; 9c, d

Two specimens of markedly different size share similar general characteristics. The smaller (Fig. 9c) is an oblique transverse section from clast PS304-3 about $13 \mathrm{~mm}$ in diameter with an intervallum $3.2 \mathrm{~mm}$ across. The outer wall is largely missing or poorly preserved, but fragments indicate that it is perforate with several small pores per intersept. The intervallum is traversed by relatively thin, coarsely porous irregular septa that may branch locally or be connected with rare synapticulae. The central cavity is filled with finely crystalline calcite and sediment; there is a thin dark margin against the inner wall of the cup that is not readily resolvable but it could be some form of finely porous mesh. Several of the septa branch close to the inner wall, suggesting the presence of pore tubes in the stirrup position. Elsewhere there appear to be at least two pores per intersept.

A second example is represented by a pair of oblique transverse (Fig. 8g) and longitudinal (Fig. 9d) sections from a large individual in clast PS304-7. Measured on the longest axis of the section, the cup diameter is $40 \mathrm{~mm}$ and the intervallum $8 \mathrm{~mm}$. Its outer 
wall is badly corroded but there are suggestions of one or possibly two rows of pores per intersept. The intervallum is traversed by proportionally thin and completely porous septa, locally joined by synapticulae. The inner wall is thin with up to four pore rows per intersept. Small spines extend from the rims of the internal pores into the central cavity (Fig. 8g left; Fig 9d).

The preservation of the specimens included here is poor, with the outer walls largely missing and considerable recrystallization. However, the structure of the intervallum and series of fine spines on the inner wall of the larger specimen, in particular, recall those of Andalusicyathus cooperi (Debrenne 1975, p. 352, fig. 10) from the Dwyka Tillite of South Africa, later transferred to Spirocyathella Vologdin by Debrenne \& Zhuravlev (1992).

Family Archaeocyathidae, Hinde 1889

Genus Pycnoidocyathus Taylor, 1910

Pycnoidocyathus sp.

Fig. 5e

A slightly oblique transverse section on slide P601024 (clast PS304-8) is from a cup about $11 \mathrm{~mm}$ in diameter (bottom of Fig. 5e). The cup outline is clearly delimited by a very thin dark layer that is probably a mineral concentration between matrix and cup, rather than a feature of the wall itself. In section, a somewhat disjunct outer wall of skeletal material is pierced locally by large rounded to polygonal pores, which could be interpreted as being “centripetally” arranged (sensu Gravestock, 1984). The intervallum is between 3 and $4 \mathrm{~mm}$ wide and is crossed by coarsely porous irregular septa or taeniae which may fork or even curve to join a neighbour; alternatively septa may be joined by sporadic synapticulae. All skeletal elements appear to be thickened, as shown by dark cores and slightly paler overgrowths. There are localised developments of vesicles. Variously blunt or hooked protuberances project into the central cavity on either side of large pore openings, one pore per intersept. The central cavity is filled with crystalline calcite and vermiform exothecal material.

Whilst there are superficial general similarities between this specimen and examples of Archaeopharetra irregularis (Taylor), described from clasts within Cenozoic glacial deposits on King George Island (Wrona \& Zhuravlev 1996, pl. 6, figs 3 \& 4), the outer wall of those specimens is not preserved well enough for comparison. Nevertheless, the wall of Archaeopharetra Debrenne is aporose (Hill 1972, p. E105), whereas that of the present 
specimen is porous. Closer affinities may lie therefore with loose material from Plunket Point, Transantarctic Mountains, described by Hill (1964b, p. 618, figs 2-19 \& 20) as Flindersicyathus ? sp. and with Flindersicyathus latiloculatus from moraine at Whichaway Nunataks (Hill 1965, p. 125, pl XI, figs 3-5), both reassigned to Pycnoidocyathus by Debrenne \& Kruse (1989). Pycnoidocyathus has a porous outer wall and pores opening into the central cavity are surrounded by curved pore tubes. It is not possible to confirm whether the pore arrangement of the outer wall is "centripetal” as defined by Gravestock (1984), but there are indications around the ‘upper margin' as seen on Fig 5e.

\section{Superfamily Metacyathoidea R. Bedford \& W.R. Bedford, 1934 \\ Family Copleicyathidae R. Bedford \& J. Bedford, 1937}

Genus Metacyathellus Debrenne \&. Zhuravlev, 1990

Metacyathellus lairdi (Hill, 1964a)

Fig. 7a, b; Fig .9a, b

Specimens included here are several fragments of transverse sections (Figs 7a, b, 9a) and a longitudinal section (Fig. 9b) in slides P537735 and P601013 (clast PS304-3). They come from cups with relatively narrow intervallar spaces and a proportionally wide central cavity; the best example (Fig. 7b) on slide P601013 would have been about $19 \mathrm{~mm}$ in diameter with a maximum intervallar width of $3 \mathrm{~mm}$. The outer wall is thin, between 0.25 and $0.28 \mathrm{~mm}$, with two or three rows of pores per intersept. On the best-preserved parts it appears to be double with a fine outer microporous sheath covering the pores. Septa are completely porous, regularly spaced and numerous (about 30 in the half cup on slide P601013). On the inner wall there are generally two rows of round pores per intersept and hints of a screen or sheath supported by fine spines. No tabulae are visible.

The transverse section on slide P537735 9 (Fig. 9a) is slightly ovate with a maximum diameter of $15.7 \mathrm{~mm}$ and a minimum diameter of $11.7 \mathrm{~mm}$; the intervallar width is about 2.6 $\mathrm{mm}$. The outer wall is about $0.5 \mathrm{~mm}$ thick with a very fine sheath supported on numerous tapered lintels. There are between one and three rows of pores per intersept. Septa are numerous (56 on the present section), coarsely porous and thicken at their junctions with the outer wall. In a few places the septa curve or are joined by synapticulae close to the inner wall. Spaces between the septa are filled with vesicles. The inner wall has one or two pores per intersept; local amalgamation of some pores on this and the other specimens gives the false impression of the presence of stirrup pores. Very fine spines, projecting from the inner wall on either side of the pores seem to support a thin microporous sheath; this is also 
apparent in Fig 7b. The central cavity is partly filled with endothecal growth and on the outer wall there are outgrowths, partly embracing the cup of another badly corroded specimen with intervallar spaces filled with crystalline calcite.

The longitudinal section is of a large conical cup $25.6 \mathrm{~mm}$ in diameter at its widest point with an intervallum about $3.4 \mathrm{~mm}$ wide and an outer wall of $0.4 \mathrm{~mm}$ thickness. The thin outer sheath supported on fine denticles is clearly seen, as is the coarsely porous nature of the septa. The interseptal spaces of the more complete individual are filled with the vesicles and the inner wall of the same individual has a thin coating of endothecal growth, but the spinose screen surrounding the pores is still visible.

In relation to the other species within the present collection, the specimens included here stand out as forming a distinct and easily recognisable group, even if their generic placement is open to discussion. In general features, the specimens recall a variety of specimens illustrated from South Australia and referred to Metaldetes Taylor, 1910, such as M. dissepimentalis (Taylor) (Gravestock, 1984, especially fig 53D, although septa in that species are commonly bifurcate) and $M$. ferulae (Gravestock 1984, p. 106, figs 53 e-j, which differs in having 'rods' projecting from interpore lintels. Closer comparisons lie with material from the Shackleton Limestone of Antarctica, first described by Hill (1964a, p.144, pl. II, figs 5a-d) as Bedfordcyathus lairdi and subsequent material used by Debrenne \& Kruse (1986, p. 266, fig. $30 \mathrm{a}, \mathrm{b})$ to augment her description and revise its generic identification with caution to Metaldetes Taylor, as their material lacked clear indications of an outer sheath. There are also resemblances to Ladaecyathus fortiseptatus Hill (1965, pl. V, figs 4 \& 5) which has stout perforate septa and inner and outer pores with spinose screens, and was reassigned to Metaldetes by Debrenne \& Kruse (1989, p. 26). The clear existence of a sheath on the outer wall in the present material, as well as a screen on the inner wall, helps clarify the generic placing of this species. The presence of a spinose screen, as opposed to a sheath on the inner wall suggests closer affinities to Metacyathellus Debrenne \& Zhuravlev (1990), as indicated by them in their reassignment of Metaldetes lairdii to that genus.

Suborder Syringocnemidina Okulitch, 1935

Superfamily Syringocnemidoidea Taylor, 1910

Family Syringocnemididae Taylor, 1910

Genus Syringocnema Taylor, 1910

Syringocnema? sp.

Fig. $8 \mathrm{f}$ 
A single slightly oblique section (P593184, clast PS 218) in a matrix of strongly recrystallised limestone shows a cup with an intervallum of hexagonal syringes, typical of the syringocnemidids (Fig. 8f). The diameter of the cup is $7.5 \mathrm{~mm}$ and the intervallar distance is $2.3 \mathrm{~mm}$; tubules range up to $0.6 \mathrm{~mm}$ diameter. On the better-preserved syringes, it is possible to see one or two pores on each facet connecting through to the adjacent tubule; some appear imperforate but the variations may be related to the angle of the section.. The outer and inner walls of the cup are corroded and their structure unclear, but the syringes appear to have large openings on the outer wall, and there is also a suggestion of a finely porous outer sheath in places. Toward the bottom of the illustration (Fig. 8f) there are traces of a ring of circular pores, about $0.3 \mathrm{~mm}$ in diameter on the inner wall.

The section was prepared from a flake taken from a specimen first illustrated by Stone \& Thomson (2005, fig. A1.f) as archaeocyath "Species 3" and compared tentatively with forms such as Flindersicyathus and Syringocnema. Features now revealed by the thin section, particularly the hexagonal syringes of the intervallum, indicate affinities within the Syringocnemidina. However, since differentiation between the constituent families is based on wall type (e.g. Debrenne 1975; Zhuravlev \& Gravestock 1994) which is not well preserved here, only an informal identification is suggested for the present material. Whilst there are general resemblances between the present specimen and Pseudosyringocnema sp., illustrated by Debrenne \& Kruse (1989, fig. 3A) from the Holyoake Range of Antarctica, and Syringocnema gracilis from a sample dredged in the Weddell Sea (Gordon 1920, p. 699, especially pl. IV, figs 44-47), the presence of up to two pores per facet suggests a closer relationship to the mono-specific genus Syringocnema (cf. Zhuravlev \& Gravestock 1994, p. 47).

Of species described from erratic material in South Africa (Debrenne 1975), the intervallum:cup diameter ratio of 0.3 , place the present specimen closer to Pseudosyringocnema gracilis (Gordon) than ?P. uniserialis (Hill). Forms referred to $P$. gracilis have now been placed in a new genus, Kruseicnema (Debrenne \& Zhuravlev 1990, p.301) which has external pore openings covered with pustules.

\section{Genera Uncertain}

Among the collection are a number of specimens which are distinctive in themselves yet whose identification is far from certain. They are included here for completeness, using informal nomenclature. 
Figure 5f; 6a, h, i

A number of sections from clast PS304-8 are all characterised by stout skeletal elements. The two best are transverse sections in slide P601026 (Fig. 6a). The largest is slightly laterally compressed with a maximum diameter of $12.9 \mathrm{~mm}$ and a minimum of 6.3 $\mathrm{mm}$; the intervallar width is $1.8 \mathrm{~mm}$ and there are 45 aporose septa. The outer wall has up to three rows of simple pores per intersept. However, in section most intersepts seem to be imperforate on the outer wall and perhaps this, and the observation that even those pores that are visible appear as shadows through the thickness of the wall, is a feature of secondary thickening and/or recrystallization. The pores of the outer wall are much clearer on an oblique section (Fig. 6h) where up to six are visible between adjacent septa. In this case the higher number of pores is probably more apparent than real, being a reflection of the obliquity of the section. The inner wall has one row of large rounded pores up to $0.4 \mathrm{~mm}$ in diameter in the stirrup position that issue from obliquely directed tubes (Fig. 6a left and 6h). No tabulae are present. Two poorly preserved specimens in a highly recrystallized matrix from clast PS303 (Figs $5 \mathrm{f}$ and 6i) have small stirrup pore canals only on the inner wall and show general similarities to Genus A. They are included here because they represent rare examples of archaeocyaths from the East Falkland outcrop of the Fitzroy Tillite Formation.

The presence of aporose septa with a single row of stirrup canals along the inner wall perhaps suggests similarity with the genus Stapicyathus Debrenne 1964. However, the outer wall in Stapicyathus incisus (Hill 1965, p. 68 pl. III, figs 2-6; Debrenne \& Kruse 1989, Fig $4 \mathrm{~d}$, e) is more distinctly porous than in the present examples, and even more so in S. stapipora (Taylor 1910, p. 118, esp. pl. VII, fig. 38; Wrona \& Zhuravlev 1996, p. 21, Pl.1, fig. 6).

\section{Genus B}

Fig. $6 g$

The identity of an otherwise distinctive transverse section, specimen P601010 (Fig. 6g), characterised by a ring of large stirrup canals around the inner wall is perhaps surprisingly problematic. Half the walls of the cup are corroded but the remnant measures approximately $9.7 \times 7.3 \mathrm{~mm}$ with an average intervallar width of $1.4 \mathrm{~mm}$. Its outer wall is finely porous with three or four pore rows per intercept. Septa are stout, aporose and thicken toward their internal extremities where they join an inner wall with large, inclined thickwalled canals. Whereas most canals appear to be confined to the stirrup position, in places it appears that there is another at a different level between successive stirrup canals. Stirrup canals have a stout spine projecting into the internal cavity. 
Genus C

Figure $6 b$

A tangential 'longitudinal' section from clast PS304-8 appears to cut entirely though the outer walls and intervallum of a cup fragment $7.9 \mathrm{~mm}$ wide at its apertural end. The outer wall has a maximum thickness of about $0.5 \mathrm{~mm}$ and is pierced by horizontal pore canals. Tabulae are common and spaced proportionally a little farther apart than the septa. Septa and tabulae are porous. Vertical, essentially single, rows of relatively large (up to $0.25 \mathrm{~mm}$ diameter) round pores between septa in the centre of the section are those of the inner wall. Multiple layers of exothecal tissue are present on the outside of the cup and there is also secondary thickening of the septa in the upper portion of the cup.

The present specimen with its thickened skeletal elements occurs in association with other robustly constructed forms here assigned to Genus A and was initially thought to belong to the same form. However Genus A lacks tabulae, much in evidence here, its outer wall is much more sparsely porous, and the pores of the internal wall are in the stirrup position. Without a transverse section that can reliably be linked to this specimen, identification is not possible. Nevertheless, its general characteristics accord with those of Coscinocyathus and allied forms.

\subsubsection{Archaeocyaths previously recorded from a hand specimen.}

The first details of archaeocyaths from the Falkland Islands were provided by Stone \& Thomson (2005) in descriptions of a hand-specimen collected at Port Purvis (PS 218, NHM PI PO 12074). As explained in section 2, no thin sections were made in order to preserve the associated trilobites and the exquisite, naturally etched faces. In fact, for the lateral section (Fig. 2) no thin section could be made since the archaeocyath specimen is a thin remnant surviving only as a surface veneer, the remainder having been eroded away. Three species of archaeocyath were identified informally as “species 1”, “species 2” and “species 3 ”.

Species 1, characterised by numerous fine, closely spaced septa and by porous tabulae that curved markedly against the outer wall, was tentatively identified as a possible member of the Coscinocyathina. A better match, however, is with Mawsonicoscinus Debrenne \& Kruse, described from the Shackleton Limestone of northern Holyoake Range, Transantarctic Mountains (Debrenne \& Kruse 1986, p. 259, fig 22). The fineness and density of septa and tabulae are similar in the Antarctic and Falkland Island specimens, and the downward curvature of the tabulae in Mawsonicoscinus sigmoides (op.cit fig 22B), to form the outer 
wall, is closely similar to that seen in the specimen illustrated by Stone \& Thomson (2005, fig. A2.a (right) and e) (Fig. 2 of this paper). Unfortunately it was not possible to examine the inner wall of the Falkland Island specimen to check for the sigmoidal pore tubes seen in $M$. sigmoides.

Species 2 was identified as a possible Thalamocyathus and there is no reason to retract from that. Among the present material are two specimens that may be confidently assigned to the genus. In particular, the characteristic annuli of the inner wall are clearly visible on all the specimens of "species 2" illustrated from Port Purvis (Stone \& Thomson 2005, figs A1. and e, A2.b-d) and compare well with the section described above as T. tectus Debrenne.

Species 3. In developing the surface of the Port Purvis clast to expose trilobite fragments, a small flake was dislodged from one of the archaeocyath specimens described as “species 3” (Stone \& Thomson 2005, fig. A1.f, tentatively identified as a possible Flindersicyathus or even Syringocnema). The flake was later prepared as a thin section and is described above as Syringocnema? sp.

6.1.2. Age and affinities of the archaeocyath fauna. The archaeocyath fauna is strongly Australo-Antarctic in character. Nine archaeocyath taxa have been identified to species level, six to generic level and another four are described under open nomenclature (Table 1). There is also one radiocyath. Of the archaeocyaths, 12 may be directly or closely compared to examples described from in situ Lower Cambrian limestone in the vicinity of the Transantarctic Mountains, or from Antarctic-derived erratic material of varying depositional ages (Permo-Carboniferous, Palaeogene, Quaternary) elsewhere in the Antarctic region. Of the Antarctic taxa, three are also present within limestone clasts recovered from Dwyka Group tillites in South Africa, with four others represented by similar forms. Twelve of the taxa from the Falkland Islands have direct or closely related equivalents in the Early Cambrian archaeocyath faunas of South Australia. Because of differences in preservation and preparation, it is difficult to compare the present material closely with occurrences recently reported from Argentina in clasts within the Cambrian, conglomeratic El Jagüelito Formation (González et al. 2011), and from reworked clasts in the Upper Carboniferous Sauce Grande Formation tillite (González et al. 2012). However, those authors pointed out that the South American faunas show close affinities with the Australo-Antarctic archaeocyath faunas and with those reported previously from the Falkland Islands.

In general, Antarctic archaeocyath faunas span the Atdabanian-Botomian interval of the Early Cambrian (e.g. Debrenne et al. 1990) with two reported exceptions. An isolated 
occurrence of Late Cambrian (Furongian) archaeocyaths has been described from the Ellsworth Mountains (Debrenne et al. 1984) and a 'post-early Cambrian' fauna from the Neptune Range of the Transantarctic Mountains (Wood et al. 1992). Apart from the Neptune Range occurrence, there is a consensus that the faunas from the Transantarctic Mountains support a Botomian age (Debrenne \& Kruse 1989). This spans, approximately, the boundary between stages 3 and 4 of Cambrian Series 2 in the proposed chronostratigraphical subdivision of the Cambrian System (Babcock et al. 2005). Although the Falklands archaeocyaths, being derived from a collection of erratic limestone blocks, may have originated from more than one stratigraphical level, a general Botomian age seems highly likely for the whole assemblage.

\subsubsection{Radiocyatha}

Class Radiocyatha Debrenne, H. Termier \& G. Termier, 1970

Family Hetairacyathidae R. Bedford \& J. Bedford, 1937

Genus Radiocyathus Okulitch, 1937

“Radiocyathus” sp.

Figs 5 d \& e

Five longitudinal to oblique transverse sections on slides P601023-25 from clast PS304-8 are from somewhat irregularly shaped conical cups with thick inner and outer walls (up to $0.8 \mathrm{~mm}$ ). The largest specimen (Fig. $5 \mathrm{~d}$ ) has a maximum diameter of $15 \mathrm{~mm}$ and an intervallum up to $5.5 \mathrm{~mm}$ wide. Both walls are porous. Variations in the shape and density of the pores in the various sections (best seen in Fig. 5d) suggest that they are irregular in form and there is no clear pattern to their arrangement. The largest pores are a little over half a millimetre in diameter. There are no septa but there are widely spaced rods or bars across the intervallum. On several sections there are fragmentary traces of a very fine microporous sheath on the outer wall (see especially Fig. 5d, bottom). The inner wall is perforate.

The thick walls and very irregular construction of the skeletal elements set these specimens apart from the more conventional archaeocyaths in the present assemblages and it is likely that they are not true archaeocyaths, at all. Probable affinities lie with Radiocyathus, although the characteristic structure of the inner and outer walls of the genus, with proximal and distal neasters at the ends of the radial rods, is not obvious. However, it is possible that there may be hints of the neasters in the sponge- or network-like structures, as seen on the inner wall in the top left of Fig. 5d, and in the centre of the upper individual in Fig. 5e. Otherwise, the structure of the cups closely resembles that seen in Radiocyathus minor W. 
Bedford \& W. R. Bedford from the Ajax Mine of South Australia (Debrenne \& Termier 1970, pl. V, fig. 1).

\subsection{Trilobites ... (A.W.A. Rushton)}

Figure 10. Individual illustrations are identified by numbers prefixed It, which are the NHM reference numbers applied to the trilobites present in the clast of Cambrian limestone from Port Purvis (PS 218, NHM PI PO 12074); at least four genera have been recognised.

Family Redlichiidae Poulsen, 1927

Genus Yorkella Kobayashi, 1942

Type species. Conocephalites australis Woodward, 1884 from the Early Cambrian of South Australia. Jell (in Bengtson et al. 1990, p. 290) revised the type species of Yorkella and illustrated a second, unnamed, species. Although he referred Yorkella to the Family Dolerolenidae of the Redlichiida, I follow Paterson \& Brock (2007), who placed it in the Family Redlichiidae.

Yorkella? sp.

Fig. 10f, i-n

Material. A glabella $8.5 \mathrm{~mm}$ long and two fragmentary cranidia, the smaller but more complete one being $7.5 \mathrm{~mm}$ long. A librigena and a fragment of a large thoracic segment are tentatively referred to the same taxon.

Description. Glabella (including LO) longitudinally convex, raised above fixigenae, slightly tapered forward, bluntly rounded anteriorly, basal width about $70 \%$ of length. Occipital furrow (SO) weak laterally and nearly obsolete at the mid-line; occipital ring without median spine or node. Glabellar furrows S1, S2, S3 very weakly expressed as slight indentations close to the axial furrow. Frontal area about $20 \%$ of glabellar length, anterior border slightly longer sagittally than the depressed preglabellar field. Eye ridge slopes back and outwards at about $50^{\circ}$ to the axial furrow, continuous with palpebral lobes, which are not completely preserved but are at least 1/3 of glabellar length and extend from opposite S2 to L1. Palpebral area of fixigena about half as wide as the width of the glabella between the eyes, gently sloping down from axial furrow to eye. Fixigenae incomplete, posterior fields broken off. Surface with subdued but fairly dense granulation.

One librigena with a subdued granulate sculpture (Fig. 10k), suggests that it may be referable to the same species as the cranidia of Yorkella?, though morphologically it is not 
much like librigenae of Yorkella figured by Jell (in Bengtson et al. 1990, figs 189, 190), which have a strong genal spine. It is more like a small librigena of Yorkella figured by Paterson \& Brock (2007, fig. 9, 14). The ocular incisure is about half as long as the genal field, which is wide. The border in our specimen is distinctive in that it narrows posterolaterally to half its anterior width. The librigenal spine is even smaller than in Paterson \& Brock’s small specimen, being no more than a pointed corner (Fig. 10k).

Figure 10k also shows the external mould of a fragment of a thoracic segment from an animal that was considerably bigger, perhaps by two or three times, than the largest cephalic fragment (Fig. 10f), but, having a similar surface sculpture, is thought to be of the same species as the cranidia.

Discussion. The cranidia have a general resemblance to those of Yorkella australis (Woodward, 1884) of comparable size, as figured by Jell (in Bengtson et al. 1990, p. 290, figs 189, 190), but they differ in several details: the Falklands specimens are slightly less convex, have a weaker occipital furrow, no occipital spine, a more transverse frontal border and wider interocular genae. The granulation on the glabella and fixigenae is of about the same density as in the Y. aff. australis figured by Paterson \& Brock (2007, Figure 9, 8). Parapaokannia sichuanensis Zhang \& Lin (in Zhang et al. 1980, pp. 199, 431, pl. 56, figs 6-10) also has a comparable cranidium with a weakly furrowed glabella, but the Falklands specimens differ in having a short but definite preglabellar field and wider interocular genae, whereas in Parapaokannia the front of the glabella slightly indents the frontal border. Species of Uktaspis (Prouktaspis) Repina (in Khomentovskiy \& Repina 1965, p.147, pl. 8, figs 5-8) are similar to the Falklands cranidia but they have slightly wider fixigenae and more divergent preocular sutures; they also have an occipital spine. Labradoria asiatica Repina (in Khomentovskiy \& Repina 1965, p.153, pl. 9, fig. 5) is also comparable, but is characterised by sharply incised glabellar furrows and a coarser granulation.

Family Namanoiidae Lermontova, 1951

Genus Chondrinouyina Repina (in Khomentovskiy \& Repina, 1965)

Type species. Chondrinouyina olekmica Repina, 1965, from the Botomian of Siberia (Khomentovskiy \& Repina 1965, p. 170).

\section{Chondrinouyina? sp.}

Fig. $10 \mathrm{a}-\mathrm{c}$

Material. Two small cranidia. 
Description. Glabella elongate, strongly convex (Fig.10c), nearly parallel-sided, width 55\%-60\% of length, bluntly rounded anteriorly. LO simple with a very small occipital node at the posterior edge. Glabellar furrows S1, S2 very faint, seen as slight depressions close to the axial furrow. No preglabellar field; anterior border forms a substantial crescentic anterior rim, sagittal length about a quarter of glabellar length. Preocular and interocular fixigenae about half as wide as glabella, postocular genae are wider, but are not well seen. Preocular sutures curve inwards forward of the palpebral lobes. Palpebral lobe nearly half as long as glabella, extends from the anterior quarter of the glabellar length to opposite the midlength of L1. Eye-ridge weakly developed, extends from the palpebral lobe sloping steeply inwards and forwards, reaching the axial furrow at about one-fifth of the glabellar length from its anterior end. Surface of glabella and fixigenae finely and densely granulose.

Discussion. The thick anterior border and absence of a preglabellar field give this taxon distinctive character, but even so, it has not been identified securely. In general aspect it resembles genera of the Family Namanoiidae, members of which are known from the later Early Cambrian of Siberia. The glabella in our specimens has about the same shape and proportions, parallel-sided and bluntly rounded in front, as Chondrinouyina olekmica Repina (in Khomentovskiy \& Repina 1965, p. 170, pl. 12, figs 10-14); the frontal border has a comparable sagittal length, the palpebral lobes are of similar length, the fixigenae are of the same width, and both taxa have a fine and dense granular sculpture. In C. olekmica the glabellar furrows are more distinct than in our specimens and the occipital ring has a short median spine rather than a tiny node.

Among other Namanoiidae, Erkelina scita Lazarenko (1962, p. 64, pl. 7, figs 7-10), from the mid-Botomian (later Early Cambrian) of northern Yakutia, has a comparable but more expanded anterior border, and differs from our cranidia in having a forwardly tapered glabella and wider interocular genae. In Tarynaspis curta Repina, which is known from the same levels as Chondrinouyina olekmica (in Khomentovskiy \& Repina 1965, p. 172, pl. 13, figs 4-7) the glabellar furrows are effaced, as in our specimens, but the glabella tapers forwards and the frontal border is not nearly so long sagittally. Juvenile specimens of Strenuella (e.g. Cobbold 1931, pl. 39, fig. 5) also show some resemblance to our Chondrinouyina?, but are generally less convex and the axial and anterior border furrows are typically rather diffuse and less well marked.

Type species. Namanoia namanensis Lermontova, 1951 


\section{Namanoia sp. juv.?}

Fig. 10g

One fragmentary cranidium was found that differs from Chondrinouyina? sp. (above) in having a thin anterior border and a forwardly tapered glabella. Two or three pairs of glabellar furrows are visible adjoining the axial furrow. The facial sutures and palpebral lobes are not well preserved and the specimen is only identified with doubt.

The thin anterior border in the present cranidium is comparable with that of Namanoia evetasica Suvorova (1960, p. 156, pl. 14, figs 10-15), but the glabella is longer and thinner than in the cranidia of Suvorova's figs $10-12$, which are 7 or $8 \mathrm{~mm}$ long. In the present specimen, which is nearly $2 \mathrm{~mm}$ long, the proportions of the glabella are much the same as in the immature cranidium $1 \mathrm{~mm}$ long illustrated by Suvorova (1960, text-fig. 52), though that specimen has a parallel-sided glabella that has not yet developed the forward taper of the adult form.

Family Edelsteinaspididae Hupé, 1953

Genus Edelsteinaspis Lermontova, 1940

Type species. Edelsteinaspis ornata Lermontova, 1940, from the later Early Cambrian of Siberia.

Suvorova (1964) placed Edelsteinaspis and the Subfamily Edelsteinaspidinae in the Order Corynexochida. Compared with most Early Cambrian polymeroid trilobites, the Corynexochida include several forms with relatively large, multi-segmented pygidia. Two pygidia were found in the clast from Port Purvis, Falkland Islands. One, which is an external mould of a tiny specimen about $1 \mathrm{~mm}$ long (Fig. 10h) shows some segmentation, but is presumably a juvenile form, maybe a meraspid, and could not be interpreted satisfactorily. The other, larger, pygidium resembles that of species of Edelsteinaspis.

\section{Edelsteinaspis? sp.}

Figs 10d, e

Description. Pygidium $3.5 \mathrm{~mm}$ long and rounded in outline posteriorly, slightly longer than a semicircle, marginate; convex, the height more than half the length (Fig. 10e). Axis as long as pygidium, composed of six axial rings and an unsegmented part behind that reaches to the border furrow; the axis has a posterior extension across the border that is regarded as a postaxial ridge, albeit an unusually broad one. Pleural fields down-sloping, composed of more than six pleurae; the anterior pleura is nearly transverse with only the tips 
curved back, defined by interpleural groove; posterior pleural furrows progressively more backwardly curved, interpleural grooves not seen. Anterior pleural bands cross the border furrow and fade out on the border, without reaching the margin. In profile the border is relatively wide, not convex. Surface appears to be smooth.

Discussion. This pygidium differs from many Early and early Middle Cambrian trilobites in being multi-segmented and lacking marginal spines. It somewhat resembles the pygidia of Edelsteinaspis, as revised by Suvorova (1964, p. 63, pls 4-7), though it differs in that the axis is proportionally narrower and the interpleural grooves are less distinct than most of the species she illustrated. In Edelsteinaspis ornata the pygidium has the anterior pleurae curved back and the anterolateral corners are rounded (Suvorova 1964, pl. 6, figs 4, 7). A more comparable species is E. biramjensis, in which the anterior pleurae are more transverse and the axis is narrower and less tapered (Suvorova 1964, pl. 7, fig. 7); the segmentation of the Falklands specimen is less distinct on both the axis and pleural regions than in $E$. biramjensis. E. gracilis and the subspecies compta differ from the Falklands specimen in having fewer segments in the pygidium and a more strongly tapered axis (idem, pl. 4, fig. 13, pl. 5, fig. 2). I have not identified a more closely similar pygidium from Early Cambrian rocks.

The present specimen contrasts strongly with the Redlichiidae, and in particular Yorkella, which has a very small spinose pygidium consisting of one segment and a terminal part. More similar are the pygidia of some Saukiandidae, such as Saukianda (Richter \& Richter 1940, pl. 1, figs 17-19), Perrector and Resserops (ibid. pl. 2, figs 31, 32, 42, 43). All these are multi-segmented and have long tapered axes, well-furrowed pleural fields and an entire border; but the Falklands specimen differs from all of them because the axis is relatively narrower and pleural fields are wide and the more anterior pleural furrows are more transverse, while the pleural furrows just extend onto the border.

6.2.1. Age and affinities of the trilobite fauna. The identifications arrived at here are tentative and do not allow a definite correlation with standard Cambrian successions, but they are comparable with taxa that occur in the Botomian of the Siberian Platform and range up to the Toyonian, or a little higher: in the projected international standard (Babcock et al. 2005), this is within Series 2, and ranges roughly from the upper part of Stage 3 and through the whole of Stage 4.

Yorkella appears to have a relatively restricted range in the Early Cambrian of Australia. It is recorded from the Parara Limestone, the Wilkawillina Limestone and the 
middle Mernmerna Limestone in South Australia (Bengtson et al. 1990, pp. 12, 13, 17; Paterson \& Brock 2007, p.120), at horizons that are correlated within the Botomian Stage of the Siberian succession (Paterson \& Brock 2007, p.121); however, the doubtfully identified Fitzroy Tillite specimens do not certainly represent Yorkella, nor do they necessarily come from the same horizon as the Australian occurrences of that genus.

Trilobites referred to the Namanoiidae are known from the upper divisions of the Early Cambrian sequences on the Siberian Platform: Chondrinouyina and Tarynaspis originate from the lowest zone of the Botomian, and Namanoia itself ranges up to the top of the Toyonian (Varmalov et al. 2008, figs 61 and 74, pp. 142 and 170). Species of Edelsteinaspis range through the later parts of Early Cambrian up to the early Middle Cambrian in Siberia (Suvorova 1964, table 86). Again, the tentative identification of the figured pygidium as a species of Edelsteinaspis does not allow a firm correlation, but if the generic identification is accepted, the pygidium from the limestone clast in the Fitzroy Tillite Formation is somewhat like the late species Edelsteinaspis biramjensis, which is of early Amgan age, or earliest Middle Cambrian of the Siberian standard.

\section{Acknowledgements.}

Thanks are due to Dr John Paterson (University of New England, Armadale, Australia) for discussion of the trilobite fragments and to Dra Susana Damborenea (Museo de Ciencias Naturales, La Plata, Buenos Aires) for advice on aspects of Argentine geology. Helpful, exhaustive reviews were provided by Prof. A Zhuralev (All Russian Geological Research Institute, St Petersburg) and Dr P D Kruse (Northern Territory Geological Survey, Australia). We also thank Phil Hurst and Phil Crabb of The Natural History Museum, London, for their photographic work on the trilobites, and Fergus Mactaggart and Sandy Henderson of the British Geological Survey, Edinburgh, for their assistance in preparing the images of the archaeocyaths. PS publishes by permission of the Executive Director, British Geological Survey, NERC, and thanks Mrs P. Rendell, Director, Falkland Islands Department of Mineral Resources, for the support provided by her department. AWAR contributes as a Research Associate of The Natural History Museum, London, and of the British Geological Survey, Keyworth. 


\section{References}

Adie, R. J. 1952. The position of the Falkland Islands in a reconstruction of Gondwanaland. Geological Magazine 89, 401-10.

Aldiss, D. T. \& Edwards, E. J. 1999. The Geology of the Falkland Islands. British Geological Survey Technical Report WC/99/10 135pp.

Amos, A. J. \& Gamundi, O. L. 1981. Late Palaeozoic Sauce Grande Formation of eastern Argentina. In Hambrey, M. J. \& Harland, W. B. (eds) Earth’s Pre-Pleistocene Glacial Record, 872-77. Cambridge: Cambridge University Press.

Babcock, L. E., Peng, S. C., Geyer, G. \& Shergold, J. H. 2005. Changing perspectives on Cambrian chronostratigraphy and progress towards subdivision of the Cambrian System. Geosciences Journal 9, 101-06.

Baker, H. A. 1924. Final Report on Geological Investigations in the Falkland Islands, 1920 1922. Stanley: Government Printer. 38pp.

Bangert, B., Stollhofen, H., Lorenz, V. \& Armstrong, R. 1999. The geochronology and significance of ash-fall tuffs in the glaciogenic Carboniferous-Permian Dwyka Group of Namibia and South Africa. Journal of African Earth Sciences 29, 33-49.

Bedford, R \& Bedford, J. 1936. Further notes on Cyathospongia (Archaeocyathi) from the Lower Cambrian of Beltana, South Australia. Memoirs of the Kyancutta Museum 3, 21-26, plates XXI-XXVI.

Bedford, R. \& Bedford, J. 1937. Further notes on Archaeos (Pleospongia) from the Lower Cambrian of South Australia. Memoirs of the Kyancutta Museum 4, 27-38, plates XXVIIXLI.

Bedford, R. \& Bedford, J. 1939. Development and classification of Archaeos (Pleospongia). Memoirs of the Kyancutta Museum 6, 67-82, plates XLII-LII.

Bedford, R. \& Bedford, W. R. 1934. New species of Archaeocyathinae and other organisms from the Lower Cambrian of Beltana, South Australia. Memoirs of the Kyancutta Museum 1, 1-7, plates I-VI.

Bedford, R. \& Bedford, W. R. 1936. Further notes on Archaeocyathi (Cyathospongia) and other organisms from the Lower Cambrian of Beltana, South Australia. Memoirs of the Kyancutta Museum, 2, 9-19, plates VII-XX.

Bellosi, E. S. \& Jalfin, G. A. 1984. Litoestratigrafia y evolucion paleoambiental Neopaleozoica de las Islas Malvinas, Argentina. Noveno Congreso Geologico Argentino, S. C. de Bariloche Actas V, 66-86. 
Bengtson, S., Conway Morris, S., Cooper, B. J., Jell, P. A. \& Runnegar, B. N. 1990. Early

Cambrian fossils from South Australia. Memoirs of the Association of Australasian

Palaeontologists 9, 1-364.

Bornemann, J. G. 1884. Uber die Fortsetzung seiner Untersuchungen Cambrischer.

Archaeocyathus-Formen und verwandter Organismen von der Insel Sardinien. Zeitschrift der

Deutschen Geologischen Gesellschaft 36, 702-06.

Buggisch, W. \& Henjes-Kunst, F. 1999. Stratigraphy, facies and provenance analyses of the Lower Cambrian Mount Wegener Formation of the Shackleton Range, Antarctica. Terra Antarctica 6, 211-28.

Caputo, M. V. \& Crowell, J. C. 1985. Migration of glacial centers across Gondwana during Paleozoic Era. Geological Society of America Bulletin 96, 1020-36.

Cobbold, E. S. 1931. Additional fossils from the Cambrian rocks of Comley, Shropshire.

Quarterly Journal of the Geological Society, London 87, 459-512.

Cooper, M. R. \& Oosthuizen, R. 1974. Archaeocyathid-bearing erratics from Dwyka Subgroup (Permo-Carboniferous) of South Africa, and their importance to continental drift. Nature 247, 396-98.

Courjault-Rade', P., Debrenne, F. \& Gandin, A. 1992. Palaeogeographic and geodynamic evolution of the Gondwana continental margins during the Cambrian. Terra Nova 4, 657-67. Craddock, J. \& Thomas, R. 2011. Detrital zircon provenance ages of the “'Dwyka Tillite”' in South Africa and the Falkland Islands. Abstract. Geosynthesis, 33-34. Cape Town.

Crowell, J. C. 1999. Pre-Mesozoic ice ages: their bearing on understanding the climate system. Geological Society of America Memoir 192, 106 pp.

Crowell, J. C. \& Frakes, L. A. 1972. Late Palaeozoic Glaciation: Part V, Karroo Basin, South Africa. Geological Society of America Bulletin 83, 2887-912.

Curtis, M. L. \& Storey, B. C. 1996. A review of geological constraints on the pre-break-up position of the Ellsworth Mountains within Gondwana: implications for Weddell Sea evolution. In Storey, B. C., King, E. C. \& Livermore, R. A. (eds) Weddell Sea Tectonics and Gondwana Break-up. Geological Society, London, Special Publication 108, 11-30. Davis, J. D., Bubela, B. \& Ferguson, J. 1978. The formation of ooids. Sedimentology 25, 703-30.

Debrenne, F. 1958. Sur quelques Archaeocyatha du Jebel Taı"ssa (Anti-Atlas occidental). Notes et Mémoires du Service Géologique du Maroc 16 (143), 59-67, 2 figs, 3 pls.

Debrenne, F. 1964. Archaeocyatha. Contribution à l'e'tude des faunes 
cambriennes du Maroc, Sardaigne et de France. Notes et Me'moires du Service Géologique du Maroc 179, 265 pp.

Debrenne, F. 1969. Lower Cambrian Archaeocyatha from the Ajax Mine, Beltana, South Australia. Bulletin of the British Museum of Natural History (Geology) 17, 295-376.

Debrenne, F. 1973. Modifications de la porosite' primaire de la muraille externe chez les archaeocyaths re'guliers. Annales de Paléontologie 59, 3-24.

Debrenne, F. 1974. Anatomie et syste'matique des archéocyathes re'guliers sans plancher d'Ajax Mine (Cambrien infe'rieur, Australie du Sud). Géobios 7, 91-138, 3 figs, pls 19-28.

Debrenne, F. 1975. Archaeocyatha provenant de blocs erratiques des tillites de Dwyka (Afrique de Sud). Annals of the South African Museum 67, 331-61.

Debrenne, F. 1989. [Favilynthidae.] In Debrenne F., Zhuravlev, A. Yu. \& Rozanov, A. Yu. [Regular archaeocyaths.] Trudy Paleontologicheskiy Institut, Akademiya Nauk SSSR 233, 1-198, 7 tbls, 70 figs, 32 pls. [In Russian.]

Debrenne, F. 1992. The archaeocyathan fauna from the Whiteout Conglomerate, Ellsworth Mountains, West Antarctica. In Webers, G. F., Craddock, C. \& Splettstoesser, J. F. (eds) Geology and Paleontology of the Ellsworth Mountains, West Antarctica. Geological Society of America Memoir 170, 279-84.

Debrenne, F., Termier, H. \& Termier, G. 1970. Radiocyatha. Une nouvelle classe d'organismes primitifs du Cambrien infe'rieur. Bulletin de la Societé géologique de France, Série 7 12, 120-25. Debrenne, F., Rozanov, A. Yu. \& Webers, G. F. 1984. Upper Cambrian Archaeocyatha from Antarctica. Geological Magazine 121, 291-99.

Debrenne, F., Rozanov, A. \& Zhuravlev, A. Yu. 1990. Regular archaeocyaths: Morphology, Systematics, Biostratigraphy, Palaeogeography, Biological affinities. Paris: Cahiers de Paleontologie, Editions du CNRS, 218 pp. [Not seen.] Debrenne, F., Zhuravlev, A. Yu. \& Kruse, P. D. 2002. Class Archaeocyatha 
Bornemann 1884. In Hooper, J. N. A. \& Van Soest, R. W.

M. (eds) Systema Porifera: a guide to the classification of sponges,

1539-699. New York: Kluwer Academic/Plenum Publishers.

Debrenne, F. \& Kruse, P. D. 1986. Shackleton Limestone archaeocyaths.

Alcheringa 10, 235-78.

Debrenne, F. \& Kruse, P. D. 1989. Cambrian Antarctic archaeocyaths.

In Crame, J. A. (ed.) Origins and Evolution of the Antarctic

Biota. Geological Society, London, Special Publication 47, 15-28.

Debrenne, F. \& Zhuravlev, A. Yu. 1990. New irregular archaeocyath

taxa. Géobios 23, 299-305.

Debrenne, F. \& Zhuravlev, A. Yu. 1992. Irregular archaeocyaths:

Morphology, Ontogeny, Systematics, Biostratigraphy, Palaeoecology.

Paris: Cahiers de Paleontologie, Editions du CNRS, 212 pp.

Du Toit, A. L. 1937. Our wandering continents. Edinburgh: Oliver \&

Boyd, 366 pp.

Frakes, L. A. \& Crowell, J. C. 1967. Facies and paleogeography of

Late Paleozoic diamictite, Falkland Islands. Geological Society of

America Bulletin 78, 37-58.

Gonza'lez, P. D., Tortello, M. F. \& Damborenea, S. E. 2011. Early

Cambrian archaeocyathan limestone blocks in low-grade metaconglomerate

from El Jagu“elito Formation (Sierra Grande, Rı́o

Negro, Argentina). Geologica Acta 9, 159-73.

Gonza'lez, P. D., Tortello, M. F., Damborenea, S. E., Naipauer, M.,

Sato, A. M. \& Varela, R. 2012. Archaeocyaths from South

America: review and a new record. Geological Journal. doi:

10.1002/gj.2415.

Gordon, W. T. 1920. Scottish National Antarctic Expedition, 1902-04:

Cambrian organic remains from a dredging in the Weddell Sea.

Transactions of the Royal Society of Edinburgh 52, 681-714.

Gravestock, D. I. 1984. Archaeocyatha from lower parts of the Lower

Cambrian carbonate sequence in South Australia. Memoir of the

Association of Australasian Palaeontologists 2, 139 pp.

Halle, T. G. 1912. On the geological structure and history of the

Falkland Islands. Bulletin of the Geological Institution of the 
University of Uppsala 11, 115-229.

Hill, D. 1964a. Archaeocyatha from the Shackleton Limestone of the Ross System, Nimrod Glacier area, Antarctica. Transactions of the Royal Society of New Zealand 2, 137-46.

Hill, D. 1964b. Archaeocyatha from loose material at Plunket Point at the head of the Beardmore Glacier. In Adie, R. J. (ed.) Antarctic Geology, 609-19. Amsterdam: North-Holland Publishing Company.

Hill, D. 1965. Archaeocyatha from Antarctica and a review of the phylum. Trans-Antarctic Expedition Scientific Reports 10, 151 pp. Hill, D. 1972. Treatise on Invertebrate Paleontology, Part E (revised), 1 Archaeocyatha. Teichert, C. (ed.) 2nd edn, 1. Boulder, Colorado and Laurence, Kansas: The Geological Society of America and University of Kansas, 158 pp.

Hinde, G. J. 1889. On Archaeocyathus, Billings, and on other genera, allied to or associated with it, from the Cambrian strata of North America, Spain, Sardinia, and Scotland. Quarterly Journal of the Geological Society, London 45, 125-48, pl. 5.

Hunter, M. A. \& Lomas, S. A. 2003. Reconstructing the SiluroDevonian coastline of Gondwana: insights from the sedimentology of the Port Stephens Formation, Falkland Islands. Journal of the Geological Society, London 160, 459-76. Hupe', P. 1953. Classification des trilobites. Annales de Paléontologie 39, 61-168.

Isbell, J. L., Lenaker, P. A., Askin, R. A., Miller, M. F. \& Babcock, L. E. 2003. Reevaluation of the timing and extent of late Paleozoic glaciation in Gondwana: role of the Transantarctic Mountains. Geology 31, 977-80.

Isbell, J. L., Koch, Z. J., Szablewski, G. M. \& Lenaker, P. A. 2008a. Permian glacigenic deposits in the Transantarctic Mountains, Antarctica. In Fielding, C. R., Frank, T. D. \& Isbell, J. L. (eds) Resolving the Late Palaeozoic Ice Age in Time and Space. Geological Society of America Special Papers 441, 59-70.

Isbell, J. L., Cole, D. I. \& Catuneanu, O. 2008b. Carboniferous- 
Permian glaciation in the main Karoo Basin, South Africa:

Stratigraphy, depositional controls, and glacial dynamics. In

Fielding, C. R., Frank, T. D. \& Isbell, J. L. (eds) Resolving the

Late Palaeozoic Ice Age in Time and Space. Geological Society of

America Special Papers 441, 71-82.

Khomentovskiy, V. V. \& Repina, L. N. 1965. [The Lower Cambrian

stratotype section of Siberia]. Akademia Nauk SSSR Sibirskoe

Otdelenie, Institut Geologii i Geofiziki, 200 pp., 14 pls. Moscow:

Nauka. [In Russian.]

Kobayashi, T. 1942. Two Cambrian trilobites from the Parara Limestone

in the Yorke's Peninsula, South Australia. Proceedings of

the Imperial Academy of Japan 18, 492-98.

Konyushkov, K. N. \& Shulyatin, O. G. 1980. [On archaeocyaths of

Antarctica and their comparison with archaeocyaths of Siberia].

In Zhuravleva, I. T. (ed.) [Cambrian of the Altay-Sayan Foldbelt],

143-50. Moscow: Nauka. [In Russian.]

Kruse, P. D. 1978. New Archaeocyatha from the Early Cambrian of

the Mt Wright area, New South Wales. Alcheringa 2, 27-47.

Kruse, P. D. 1982. Archaeocyathan biostratigraphy of the Gnalta

Group at Mt Wright, New South Wales. Palaeontographica A177, 129-212.

Laird, M. G. \& Bradshaw, J. D. 1982. Uppermost Proterozoic and Lower Palaeozoic geology of the Transantarctic Mountains. In

Craddock, C. (ed.) Antarctic Geoscience, 525-33. Madison: The

University of Wisconsin Press.

Lazarenko, N. P. 1962. [New Lower Cambrian trilobites from the

Soviet Arctic]. Sbornik Statei po Paleontologii i Biostratigrafii.

Nauchno-Issledovatelskii Institut Geologi Arktiki (NIIGA) 29, 29-

78, 8 pls. [In Russian.]

Lermontova, E. V. 1940. [Class Trilobita]. In Vologdin, A. G. [Atlas of

characteristic forms of the fossil faunas of the USSR. 1. Cambrian],

112-62, pls 35-49. Moscow, Leningrad. [In Russian.]

Lermontova, E. V. 1951. [Lower Cambrian trilobites and brachiopods

from Eastern Siberia]. Vsesoyuzniy Nauchno-Issledovatel'skii Geologicheskii 
Institut (VSEGEI). 218 pp., 21 pls. Moscow. [In

Russian.]

Marshall, J. E. A. 1994. The Falkland Islands: a key element in

Gondwana palaeogeography. Tectonics 13, 499-514.

Matsch, C. L. \& Ojakangas, R. W. 1992. Stratigraphy and sedimentology

of the Whiteout Conglomerate: an Upper Paleozoic glacigenic

unit, Ellsworth Mountains, West Antarctica. In Webers, G.

F., Craddock, C. \& Splettstoesser, J. F. (eds) Geology and

Paleontology of the Ellsworth Mountains, West Antarctica. Geological

Society of America Memoir 170, 37-62.

Moore, J. M. \& Moore, A. E. 2004. The roles of primary kimberlitic

and secondary Dwyka glacial sources in the development of

alluvial and marine diamond deposits in Southern Africa. Journal

of African Earth Sciences 38, 115-34.

Morycowa, E., Rubinowski, Z. \& Tokarski, A. K. 1982. Archaeocyathids

from a moraine at Three Sisters Point, King George

Island (South Shetland Islands, Antarctica). Studia Geologica

Polonica 74, 73-80.

Okulitch, V. J. 1935. Cyathospongia - a new class of Porifera to

include the Archaeocyathinae. Transactions of the Royal Society

of Canada 3 (IV), 75-106, 3 figs, 2 pls.

Okulitch, V. J. 1937. Changes in nomenclature of Archaeocyathi

(Cyathospongia). Proceedings of the Geological Society of

America 1936, 358.

Oosthuizen, R. D. F. 1981. An attempt to determine the provenance of the southern Dwyka from palaeontological evidence. Palaeontologica Africana 24, 27-29.

Palmer, A. R. 1973. Cambrian trilobites. In Hallam, A. (ed.) Atlas of Palaeobiogeography, 3-11. Amsterdam, London, New York:

Elsevier.

Palmer, A. R. 1998. Why is intercontinental correlation within the

Lower Cambrian so difficult? Revista Española de Paleontología, nu'mero extraordinario Homenaje al Profesor Gonzalo Vidal, 17-

21. Granada: Sociedad Española de Paleontologı́a. 
Palmer, A. R. \& Rowell, A. J. 1995. Early Cambrian trilobites from the Shackleton Limestone of the central Transantarctic Mountains. Paleontological Society Memoirs 45, 1-28.

Paterson, J. R. \& Brock, G. A. 2007. Early Cambrian trilobites from Angorichina, Flinders Ranges, South Australia, with a new assemblage from the Pararia bunyerooensis Zone. Journal of Paleontology 81, 116-42.

Pegel, T. V. 2000. Evolution of trilobite biofacies in Cambrian basins of the Siberian Platform. Journal of Paleontology 74, 1000-19. Poulsen, C. 1927. The Cambrian, Ozarkian, and Canadian faunas of northwest Greenland. Meddelelser om Grønland 70, 233-343, pls $14-21$.

Repina, L. N. 1965. [Chondrinouyina olekmica.] In Khomentovskiy, V. V. \& Repina, L. N. [The Lower Cambrian stratotype section of Siberia.] Akademia Nauk SSSR Sibirskoe Otdelenie, Institut Geologii i Geofiziki. Moscow: Nauka, 200 pp., 14 pls. [In Russian.] Richards, P. C., Gatliff, R. W., Quinn, M. F., Williamson, J. P. \& Fannin, N. G. T. 1996. The geological evolution of the Falkland Islands continental shelf. In Storey, B. C., King, E. C. \& Livermore, R. A. (eds) Weddell Sea Tectonics and Gondwana Break-up. Geological Society, London, Special Publications 108, 105-28.

Richter, R. \& Richter, E. 1940. Die Saukiander-Stufe von Andalusien. Abhandlungen der Senckenbergischen Naturforschenden Gesellschaft 450, 1-88, 5 pls.

Rozanov, A. Yu. 1966. [Tumuliolynthidae]. In Rozanov, A. Yu. \& Missarzhevskiy, V. V. [Biostratigraphy and fauna of the lower horizons of the Cambrian], 65. Trudy, Geologicheskiy Institut, Akademiya Nauk SSSR 148, 1-216, 68 figures, 13 plates. Moscow: Nauka. [In Russian.] Rozanov, A. Yu. \& Debrenne, F. 1974. Age of archaeocyathid assemblages. American Journal of Science 274, 833-48. Scotese, C. R., Boucot, A. J. \& McKerrow, W. S. 1999. Gondwanan palaeogeography and palaeoclimatology. Journal of African Earth 
Sciences 28, 99-114.

Stone, P. \& Rushton, A. W. A. 2003. Some new fossil records and notabilia from the Falkland Islands. The Falkland Islands Journal 8 (2), 1-10.

Stone, P. \& Rushton, A. W. A. 2012. The pedigree and influence of fossil collections from the Falkland Islands: from Charles Darwin to continental drift. Proceedings of the Geologists' Association 123, 520-32.

Stone, P. \& Thomson, M. R. A. 2005. Archaeocyathan limestone blocks of likely Antarctic origin in Gondwanan tillite from the Falkland Islands. In Vaughan, A. P. M., Leat, P. T. \& Pankhurst, R. J. (eds) Terrane Processes at the Margins of Gondwana. Geological Society, London, Special Publications 246, 347-57. Storey, B. C., Curtis, M. L., Ferris, J. K., Hunter, M. A. \& Livermore, R. A. 1999. Reconstruction and break-out model for the Falkland Islands within Gondwana. Journal of African Earth Sciences 29, 153-63.

Suvorova, N. P. 1960. [Trilobites from the Cambrian of the eastern Siberian Platform. Part 2. Olenellidae - Granulariidae]. Trudy Paleontologicheskogo Instituta, Akademiya Nauk SSSR 84, 238 pp, 16 pls. [In Russian.]

Suvorova, N. P. 1964. [Trilobites of the Corynexochoidea and their historical development]. Trudy Paleontologicheskogo Instituta, Akademiya Nauk SSSR 103, 320 pp, 31 pls. [In Russian.]

Taylor, T. G. 1910. The Archaeocyathinae from the Cambrian of South Australia with an account of the morphology and affinities of the whole class. Memoirs of the Royal Society of South Australia 2, 55-188.

Taylor, T. G. 1914. Short notes on palaeontology. British Antarctic Expedition 1907-09. Reports on the Scientific Investigations:

Geology 1, 240. London: Heinemann.

Torsvik, T. H., Smethurst, M. A., Meert, J. G., van der Voo, R., McKerrow, W. S., Brasier, M. D., Sturt, B. A. \& Walderhaug, H. J. 1996. Continental break-up and collision in the Neoproterozoic 
and Palaeozoic. A tale of Baltica and Laurentia. Earth-Science Reviews 40, 229-58.

Torsvik, T. H. \& Cocks, L. R. M. 2011. The Palaeozoic palaeogeography of central Gondwana. In Van Hinsbergen, D. J. J., Buiter, S. J. H., Torsvik, T. H., Gaina, C. \& Webb, S. J. (eds) The Formation and Evolution of Africa: A Synopsis of $3 \cdot 8 \mathrm{Ga}$ of Earth History. Geological Society, London, Special Publications 357, 137-66.

Trewin, N. H., Macdonald, D. I. M. \& Thomas, C. G. C. 2002. Stratigraphy and sedimentology of the Permian of the Falkland Islands: lithostratigraphic and palaeoenvironmental links with South Africa. Journal of the Geological Society, London 159, 5-19. Varmarlov, A. I., Rozanov, A. Yu., Khomentovskiy, V. V., Shabanov, Yu. Ya. \& 13 others. 2008. The Cambrian System of the Siberian Platform. Part 1: the Aldan-Lena Region. Moscow - Novosibirsk: PIN RAS, 300 pp. [In Russian and English.] Veevers, J. J. \& Powell, C. McA. 1987. Late Palaeozoic glacial episodes in Gondwanaland reflected in transgressive-regressive depositional sequences in Euramerica. Geological Society of America Bulletin 98, 475-87.

Visser, J. N. J., Hall, K. J. \& Loock, J. C. 1986. The application of stone counts in the glacigene Permo-Carboniferous Dwyka Formation, South Africa. Sedimentary Geology 46, 197-212. Vologdin, A. G. 1939. [Middle Cambrian archaeocyaths and algae of the South Urals.] Problemy Paleontologii 5, 209-45 [In Russian], 245-76 [In English.]

Vologdin, A. G. 1956. [On the classification of the phylum Archaeocyatha.]

Doklady Akademii Nauk SSSR 111 (4), 877-80. [In

Russian.]

Wood, R. A., Evans, K. R. \& Zhuravlev, A. Yu. 1992. A new post-early Cambrian archaeocyath from Antarctica. Geological Magazine 129, 491-95.

Woodward, H. 1884. Note on the remains of trilobites from South Australia. Geological Magazine Decade 3 1, 372-74. 
Wrona, R. \& Zhuravlev, A. Yu. 1996. Early Cambrian archaeocyaths from glacial erratics of King George Island (South Shetland Islands), Antarctica. Palaeontologia Polonica 55, 9-36. Zhang Wentang, Lu Yanhao, Zhu Zhaoling, Qian Yiyang, Lin Huanling, Zhou Zhiyi, Zhang Shengui \& Yuan Jinliang. 1980. [Cambrian trilobite faunas of southwestern China]. Palaeontologica Sinica 159 (New Series B, No. 16), 497 pp., 134 pls. [In Chinese with English summary.]

Zhuravlev, A. Yu. \& Gravestock, D. I. 1994. Archaeocyaths from Yorke Peninsula, South Australia and archaeocyathan Cambrian zonation. Alcheringa 18, 1-54.

Zhuravleva, I. T. 1956. [Salairocyathoidea]. In Vologdin, A. G. [On the classification of the phylum Archaeocyatha]. Doklady Akademii Nauk SSSR 111 (4), 879. [In Russian.]

Zhuravleva I. T. 1963. [Archaeocyaths of Siberia. One-walled archaeocyaths (orders Monocyathida and Rhizacyathida)]. Moscow: Nauka, 199 pp., 22 tables, 68 figures, 12 plates. [In Russian.]

Zhuravleva I. T. 1964. [Kijacyathidae]. In Repina, L. N., Khomentovskiy, V. V., Zhuravleva I. T. \& Rozanov, A. Yu. [Lower Cambrian biostratigraphy of the Sayan-Altay Fold Belt], 195. Moscow: Nauka, 364 pp., 20 tables, 56 figures, 48 plates. [In Russian.]

\section{Figure captions}

Figure 1. Outline geology of the Falkland Islands, showing the outcrop of the Fitzroy Tillite Formation, after Aldiss and Edwards (1999). The very narrow outcrop of the Lafonia Group succession beneath the Fitzroy Tillite Formation cannot be shown at the scale of the map.

Figure 2. A lateral section through an archaeocyath (Mawsonicoscinus sigmoides Debrenne \& Kruse, 1986) seen on the wind-abraded surface of a limestone clast from the Fitzroy Tillite Formation at Port Purvis, showing the fine detail within the perimeter wall. The specimen is preserved only as a thin veneer on the rock surface. NHM catalogue number PI PO 12074; field/working number PS218; BGS image number P511905.

Figure 3. Two general views of thin sections of archaeocyath-bearing limestone clasts from the Fitzroy Tillite Formation of Hill Cove, West Falkland, showing the diversity of forms preserved: (a) Clast with Metacyathellus lairdi (Hill, 1964) (left and centre), scattered ?Erismacoscinus sp., a small transverse section of Tumuliolynthus irregularis (R. Bedford \& 
W. R. Bedford, 1934) in centre just below NW-SE mineral-filled crack, and Spirocyathella cf. cooperi (Debrenne, 1975) sp. (bottom left). Specimen P537735, x 2; (b) Clast with Pycnoidocyathus sp. (top right) "Radiocyathus" sp. (top right edge), Ethmocyathus cf. lineatus Bedford \& Bedford, 1934 (centre left), Genus A sp. (bottom left) and “Protophaeretra” sp. (centre right). Specimen P601024, x 2.

Figure 4. Alternative reconstructions of the Falklands sector of Gondwana showing directions of ice-flow during the late Carboniferous glaciation: (a) rotation of a Falklands microplate, controlled largely by onshore geological evidence (e.g. Marshall 1994; Storey et al. 1999; Trewin et al. 2002); (b) current position of the Falklands maintained, controlled largely by offshore geological evidence (e.g. Richards et al. 1996). Ice-flow directions from: Frakes \& Crowell (1967) for the Falkland Islands; Moore \& Moore (2004) for South Africa; Curtis \& Storey (1996) for the Ellsworth Mountains. These are representative sketches balancing input from a number of sources and we do not claim palaeogeographical precision.

Figure 5. Archaeocyaths from clasts within the Fitzroy Tillite Formation of the Falkland Islands. (a-e and g) all from Hill Cove, West Falkland; (f) from East Falkland. (a) Favilynthus cf. contractus (Hill, 1965), oblique section of an example with an invaginated wall, P601023, x 2. (b) Favilynthus cf. contractus (Hill, 1965), transverse section, P601022, x 2. (c) Favilynthus cf. contractus (Hill, 1965), tangential section from the wall of a cup, P601016, x 5. (d) “Radiocyathus” sp., longitudinal section showing intervallar rods and possible neasters, P601025, x 5. (e) “Radiocyathus" sp., three longitudinal to oblique sections; also an oblique transverse section of Pycnoidocyathus sp. (bottom of illustration), P601024, x 5. (f) Genus A sp., transverse section of a small specimen showing large stirrup canals on the inner wall, P601008, x 5. (g) Flexanulus cf. oosthuizeni Debrenne, 1975, slightly oblique longitudinal section showing the characteristic flexed annuli of the genus, P601013, x 7.5.

Figure 6. Archaeocyaths from clasts within the Fitzroy Tillite Formation of the Falkland Islands. (a-h) all from Hill Cove, West Falkland; (i) from East Falkland. (a) Genus A sp. nov.?, two transverse sections, P601026, x 5. (b) Genus C sp., longitudinal section tangential to the inner wall, P601028, x 5. (c) Thalamocyathus trachealis (Taylor, 1910), partially oblique transverse section, showing porous outer wall; Tumuliolynthus irregularis (R. Bedford \& W. R. Bedford, 1934), upper left side shows part of a longitudinal section, 
P601012, x 7.5. (d) Thalamocyathus sp., transverse section showing robust annuli of the inner wall, P601021, x 7.5. (e) Ethmocyathus lineatus Bedford \& Bedford, 1934, slightly oblique transverse section, P601024, x 5. (f) Ethmocyathus lineatus Bedford \& Bedford, 1934, longitudinal section showing series of annuli crossing the pore canals of the inner wall, P601023, x 5. The form at centre left is an indeterminate archaeocyathine. (g) Genus B sp., partially corroded oblique section, P601010, x 7.5. Note associated microbial structures. (h) Genus A sp., oblique longitudinal section, showing details of stirrup canals in the inner wall, P601024, x 5. (i) Genus B sp., badly corroded transverse section showing general similarities to the example in Fig. 6g, P601007, x 5.

Figure 7. Archaeocyaths from clasts within the Fitzroy Tillite Formation of the Falkland Islands; all from Hill Cove, West Falkland: (a) Metacyathellus lairdi (Hill, 1964), parts of a crushed oblique section, P601013, x 5; (b) Metacyathellus lairdi (Hill, 1964), incomplete transverse section from a cup with a wide central cavity, P601013, x 5; (c) section showing species with finely constructed skeletal elements; left, ?Polycoscinus sp.; right, ?Erismacoscinus sp., P537735, x 5; (d) right, Poroscinidae indet., incomplete transverse section, P537735, x 7.5; (e) Polycoscinus cf. papillatus (Bedford \& Bedford, 1934), transverse sections of a cup joined by exothecal material to a second cup, possibly of the same species, P601025, x 5; (f) Polycoscinus cf. papillatus (Bedford \& Bedford, 1934), enlargement of the transverse section in fig 7e, x 7.5.

Figure 8. Archaeocyaths from clasts within the Fitzroy Tillite Formation of the Falkland Islands; all from Hill Cove, West Falkland: (a) Polycoscinus scutatus? (Hill, 1965), oblique longitudinal section in a highly recrystallised matrix. Note the spines on the internal wall. P601015, x 5; (b) Polycoscinus scutatus (Hill, 1965), part of an oblique transverse section showing the attached microporous sheath, P601016, x 6; (c) "Protophaeretra" sp., longitudinal sections of rod- and platelet-rich individuals growing in close juxtaposition, P601024, x 5; (d \& e) “Protophaeretra” sp., fragments from forms resembling $P$. pauciseptata (Gordon), P601013, x 5; (f) ? Syringocnema sp., oblique transverse section in a highly recrystallised limestone matrix, P593184, x 5; (g) Spirocyathella cf. cooperi (Debrenne, 1975), P601019, x 4.

Figure 9. Archaeocyaths from clasts within the Fitzroy Tillite Formation of the Falkland Islands; all from Hill Cove, West Falkland: (a) Metacyathellus lairdi (Hill, 1964), transverse 
section (top left) linked by exothecal outgrowth to a second badly corroded specimen. Also present are sections through ?Erismacoscinus sp. P537735, x 5; (b) Metacyathellus lairdi, longitudinal section from the upper part of a large cup, P601012, x 5; (c) Spirocyathella cf. cooperi (Debrenne, 1975), transverse section, P537735, x 3; (d) Spirocyathella cf. cooperi (Debrenne, 1975), detail of a longitudinal section, P601018, x 5.

Figure 10. Trilobites from a cobble of archaeocyathan limestone from Port Purvis: PS 218, specimen number NHM PI PO 12074 in the collection of the Palaeontological Department of The Natural History Museum, London. (a-c) Chondrinouyina sp., all x 12: (a) rubber cast of cranidium showing the salient frontal border, It 28330; (b, c) top and left side view of cranidium, It 28331. (d, e) Edelsteinaspis? pygidium, top and right side views, x 6, It 28332. (f) Yorkella? sp. glabella, x 3, It 28333. (g) Namanoia? sp. juv., cranidium, x 12. It 28334. (h) rubber cast of undetermined juvenile pygidium, x 12. It 28328. (i-j, k?, l-n) Yorkella? sp.: (i, j) cranidial fragment, left side and top views, x 3, It 28327. The Chondrinouyina in Fig. 10a is in the lower right corner; (k) librigena tentatively assigned to Yorkella?, x 6, It 28329. It is associated with a large thoracic segment showing sculpture similar to the specimens of Yorkella? (counterpart of It 28335). The pygidium, Fig. 10h, lies to the right of the librigena; (l-n) cranidium, top, front and side views, x 6, It 28328. All figures (C) The Natural History Museum, London.

\section{Table Captions}

Table 1. Faunal assemblages of archaeocyaths in limestone clasts from the Fitzroy Tillite Formation of the Falkland Islands. All of the thin sections listed contain archaeocyaths, but where rows are left blank, only fragmentary and/or indeterminate forms are present.

Table 2. Correlation of working, image and NHM catalogue numbers for the archaeocyath-bearing limestone clasts.

Working number: field collecting localities (Fig. 1) are identified as PS 218 (Port Purvis, West Falkland), PS 303 (Frying Pan Quarry, East Falkland) and PS 304 (Hill Cove, East Falkland); individual clasts collected (when more than one) are identified by the number following the hyphen, e.g. PS 304-8; where more than one thin section was cut from each 
clast, they are identified by letter, e.g. PS 304-8b; thin sections cut orthogonal to each other are identified by a superscript 1, e.g. PS 304-8b and PS 304-8b ${ }^{1}$.

Description: HS = hand specimen; TS = thin section, standard format unless specified as (large), in which case the section is twice the standard size.

BGS image number: reference number for the scanned image of each thin section held in the photographic archive of the British Geological Survey.

NHM catalogue number: Palaeontological Department collection, a dollar sign (\$) following the number indicates a thin section. 

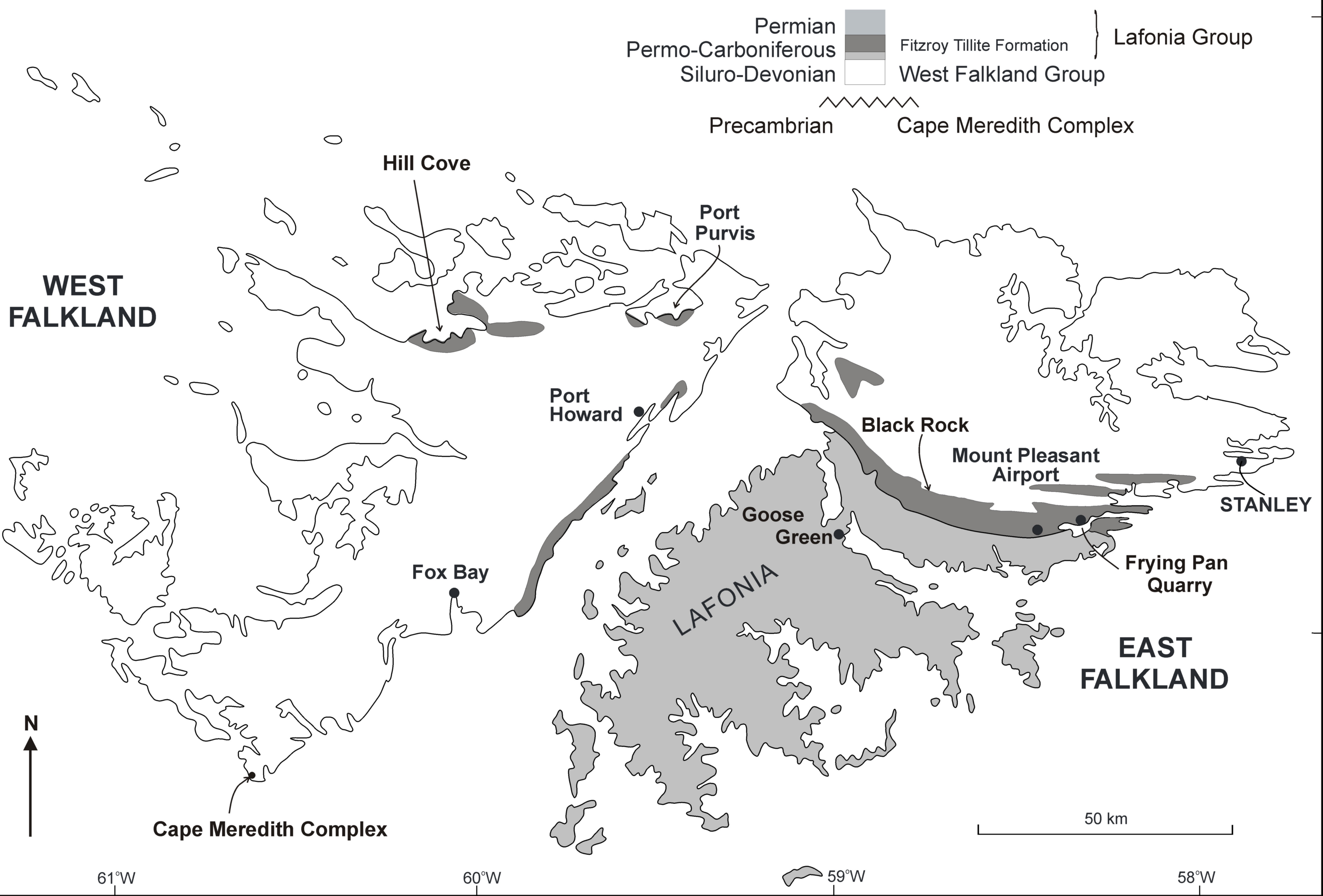


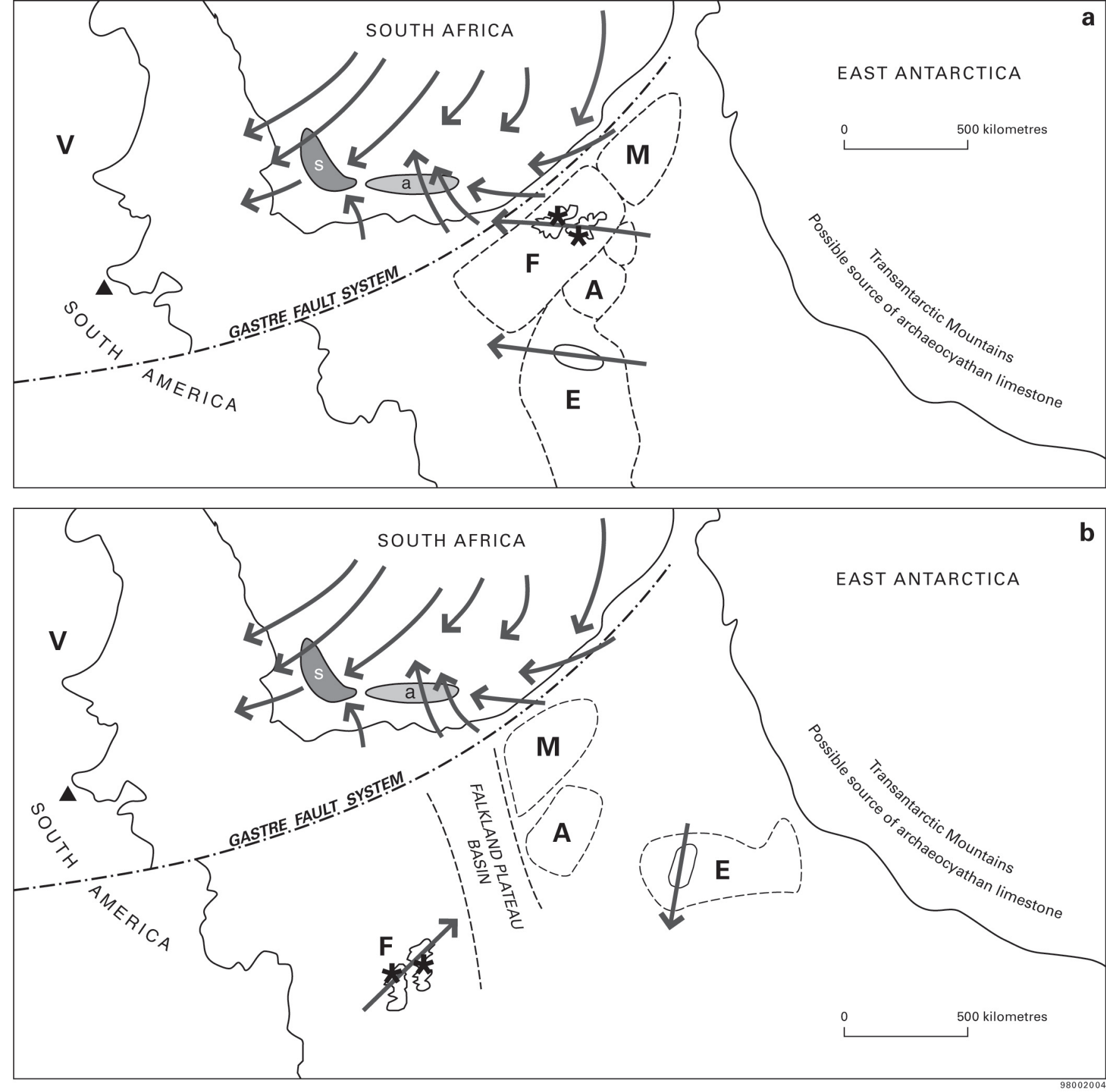

a Dwyka Tillite in this area contains clasts of archaeocyathan limestone

S Dwyka Tillite in this area contains clasts of stromatolitic limestone

- Archaeocyathan limestone clasts reported from a Cambrian conglomerate
Direction of ice flow $\quad \mathbf{A}$ Agulhas Plateau

E Ellsworth Mountains

F Falkland Plateau
M Maurice Ewing Bank

V Ventania, Argentina

Location of archaeocyathan limestone in Fitzroy Tillite 


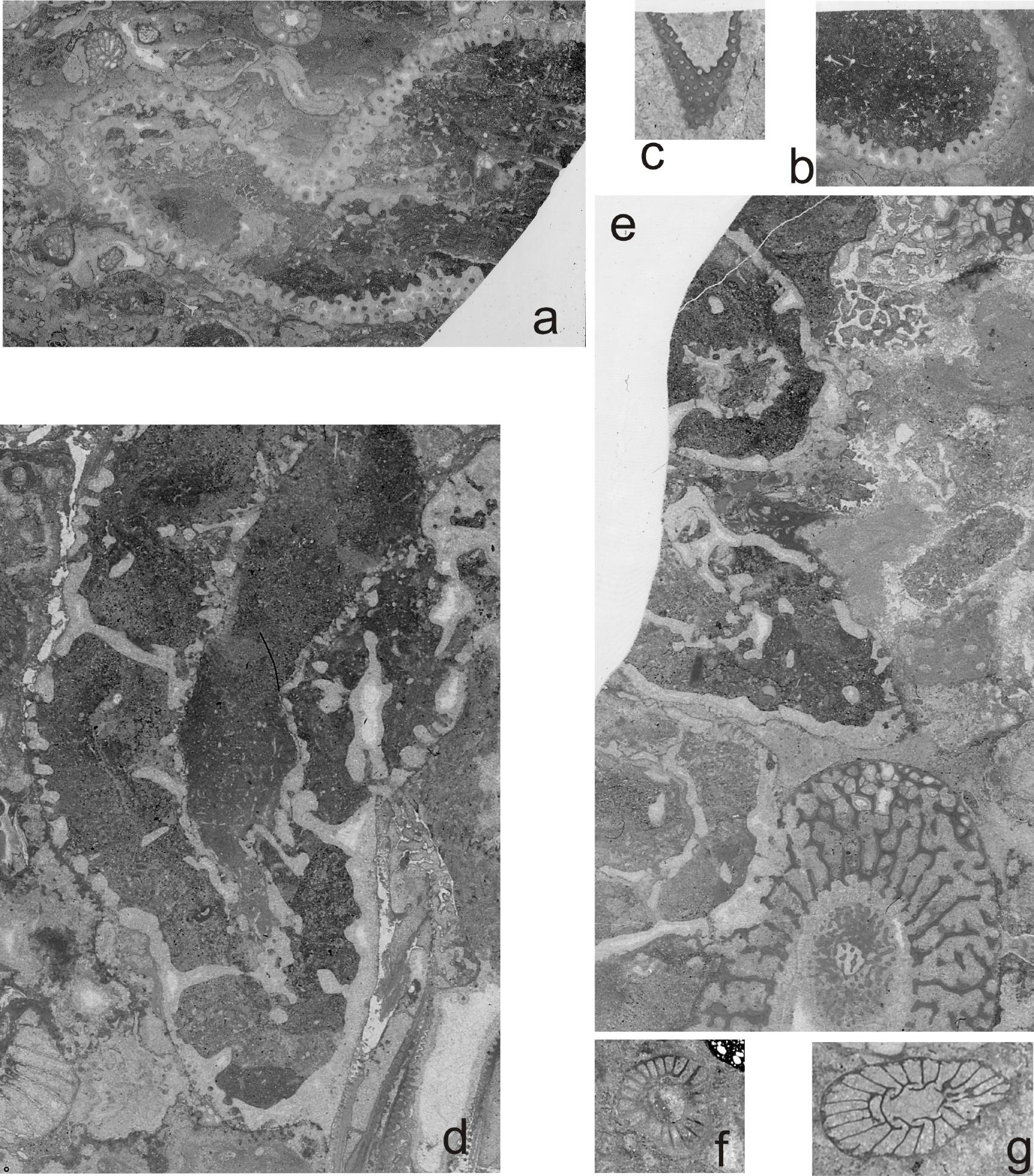



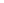


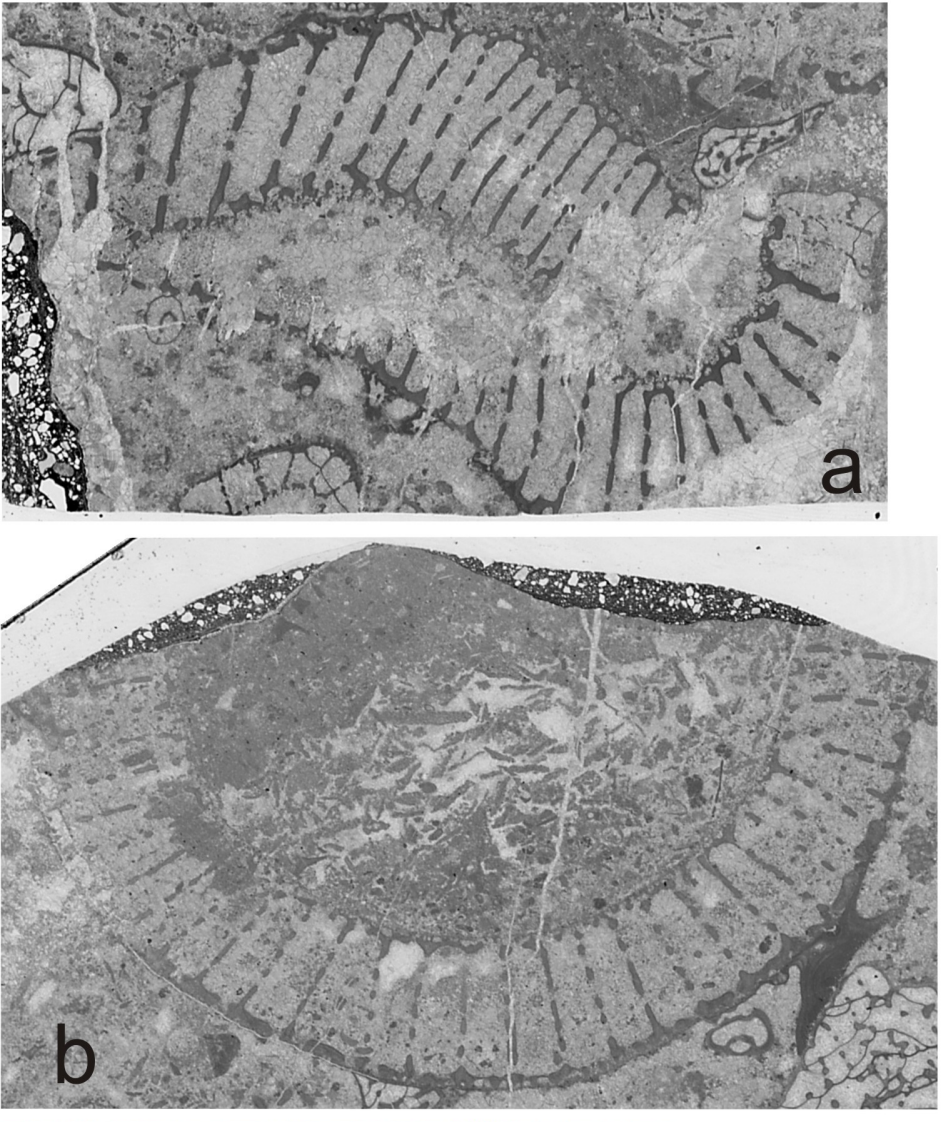

(1) I ?

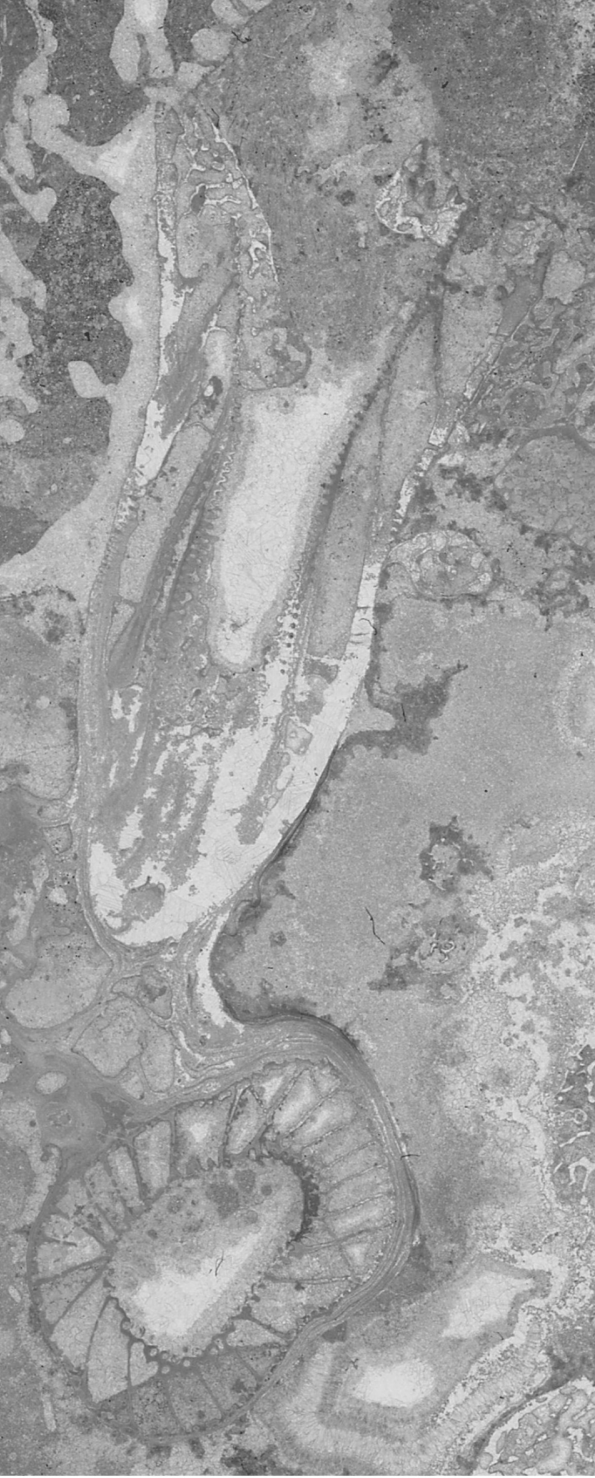

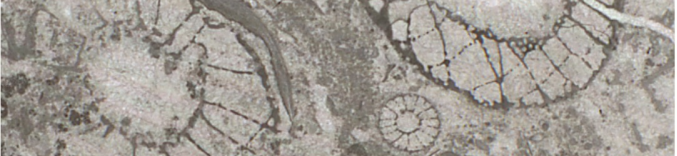

d

$x^{2}=0$

(a)

(6) 2025 (a) (2) $\frac{25}{5} \div \because 3$

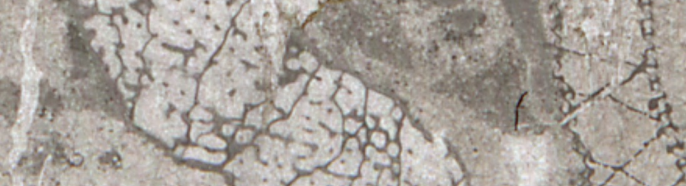

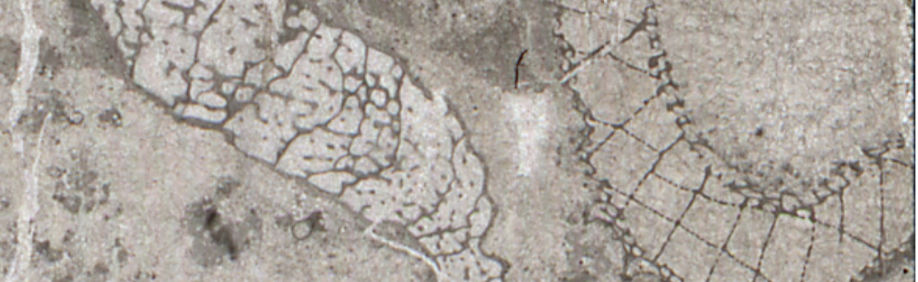

to.

beostin

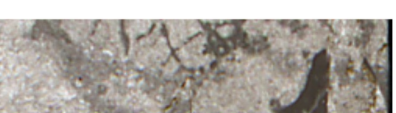
1.

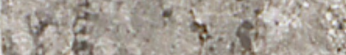
S. 6 क

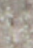
$+\log$

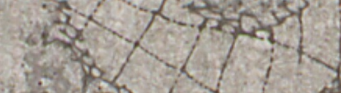
4 क्रा 

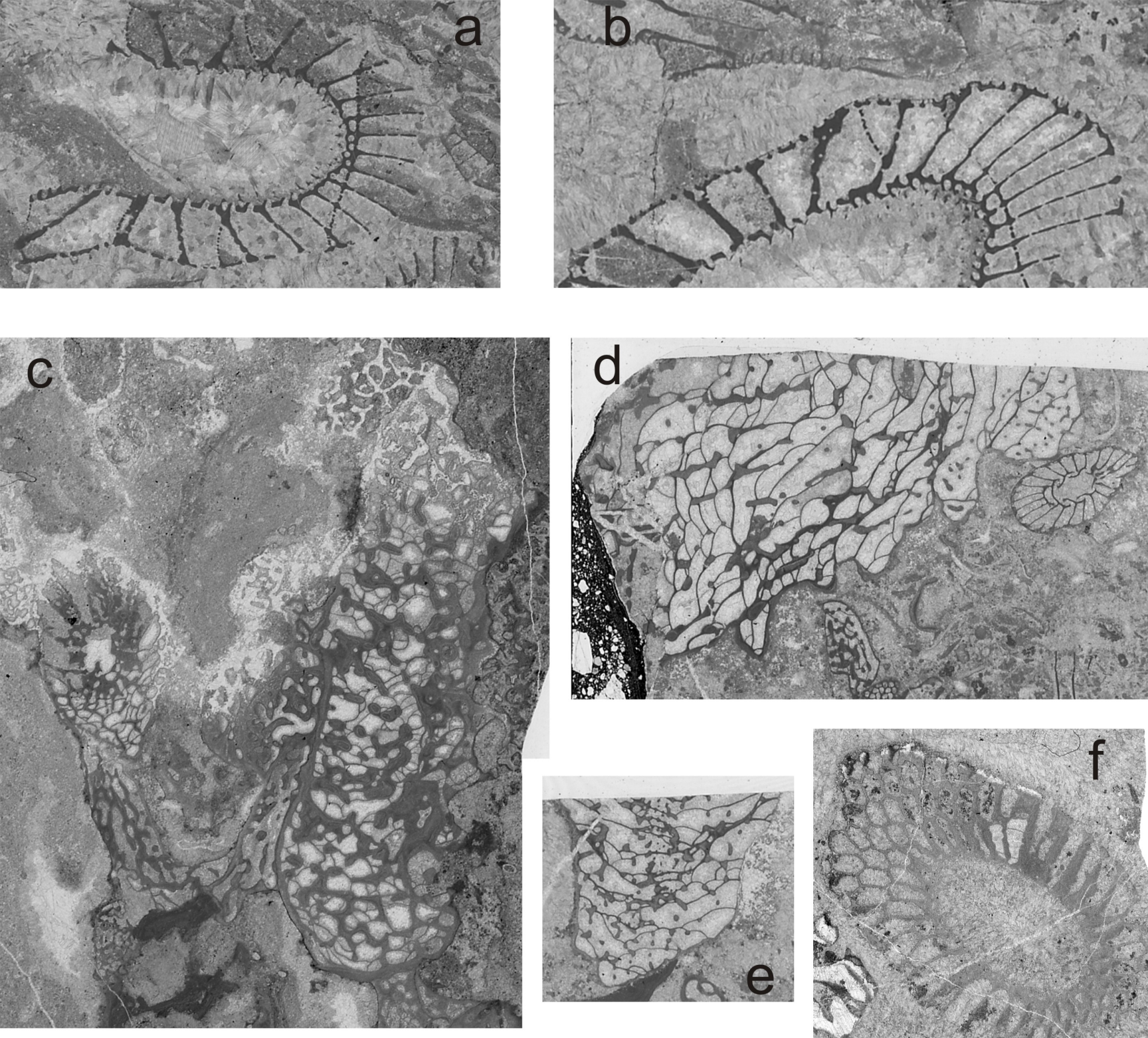
15 -
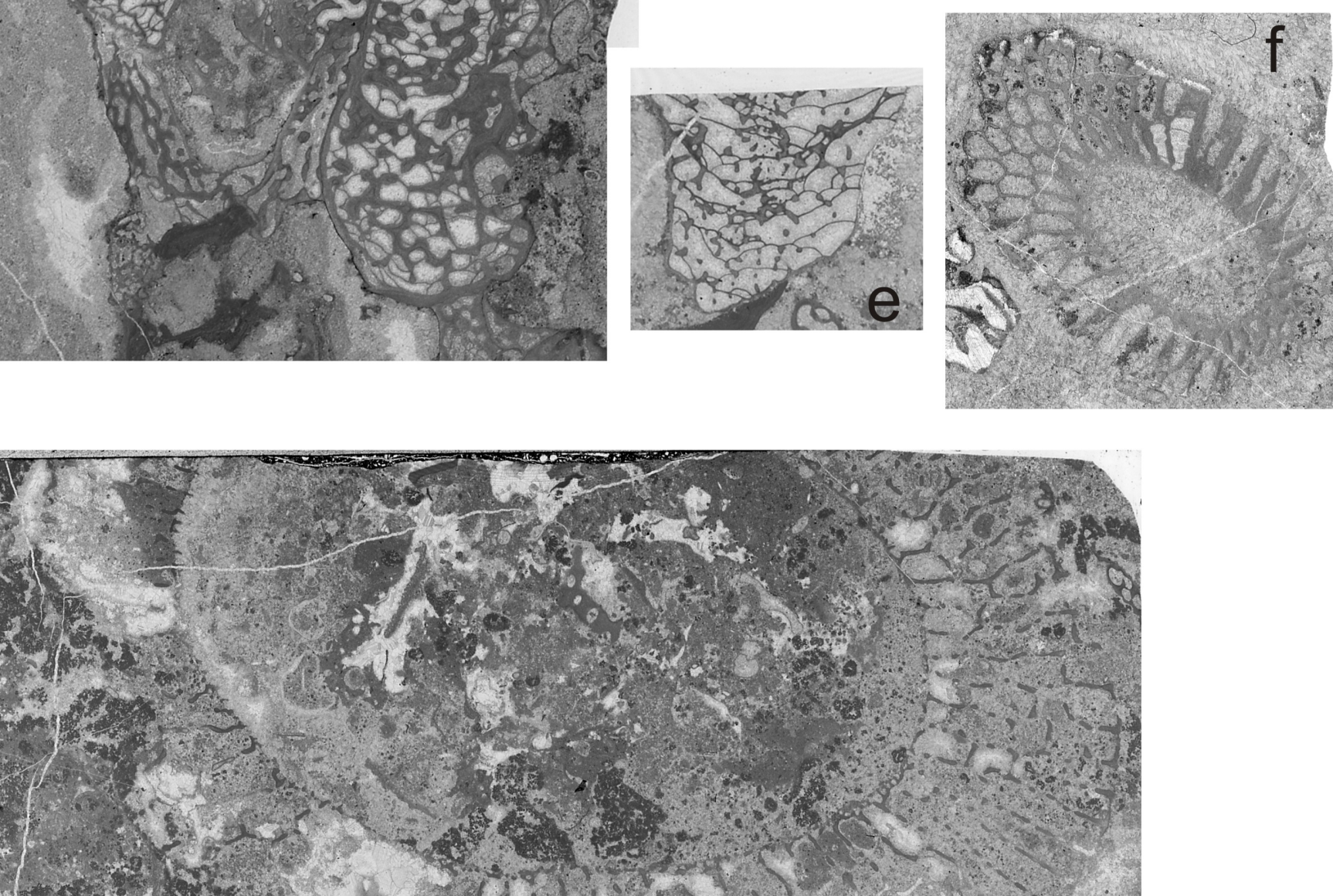

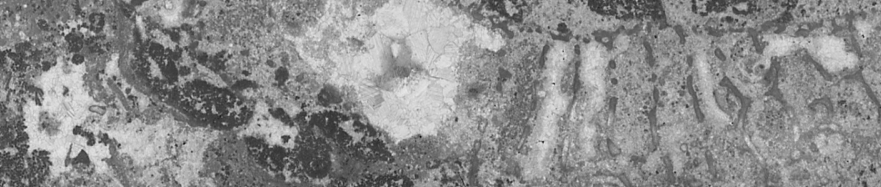
is $6 y^{2}$ 
(3)

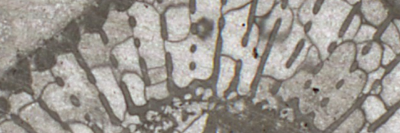

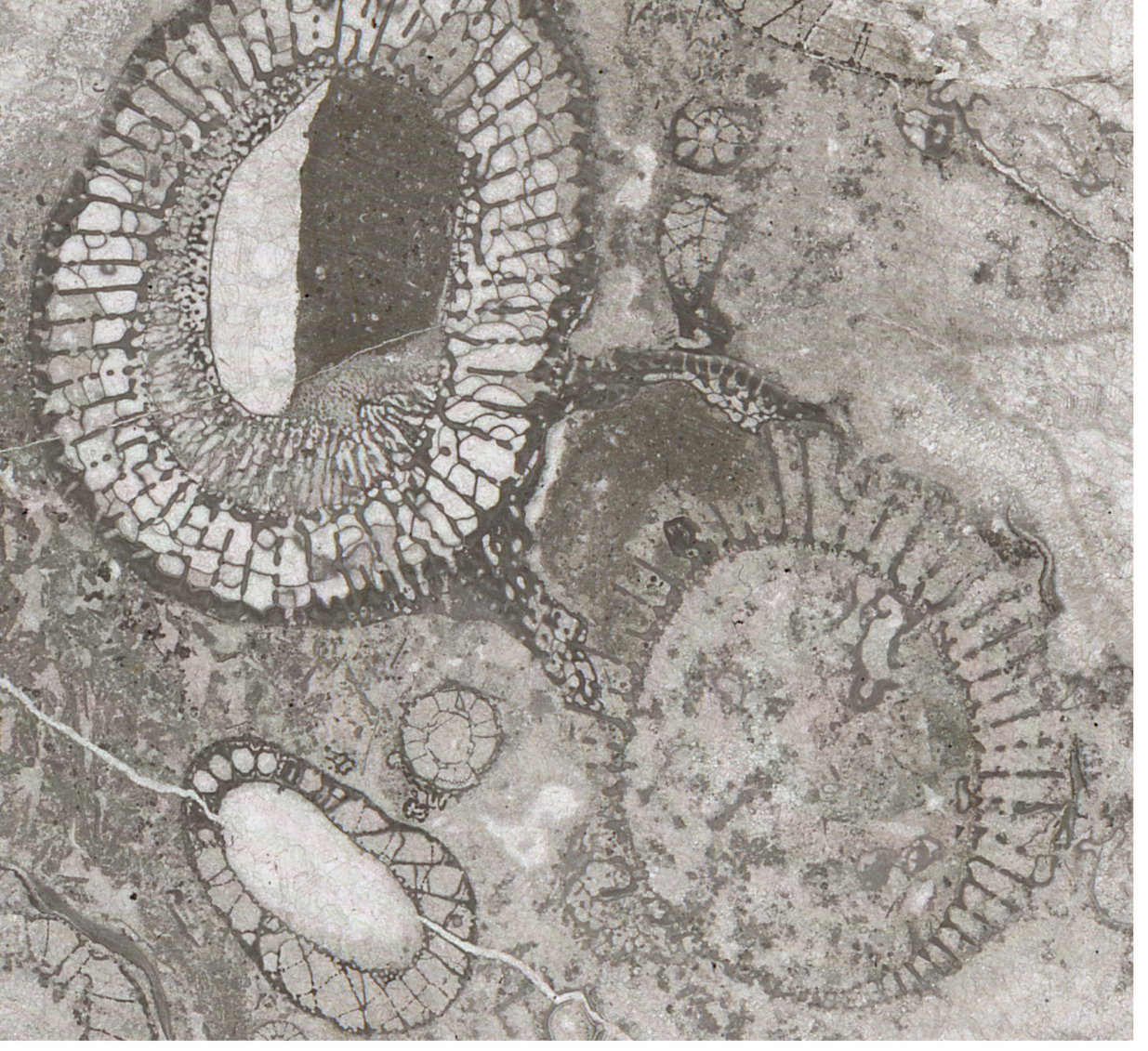

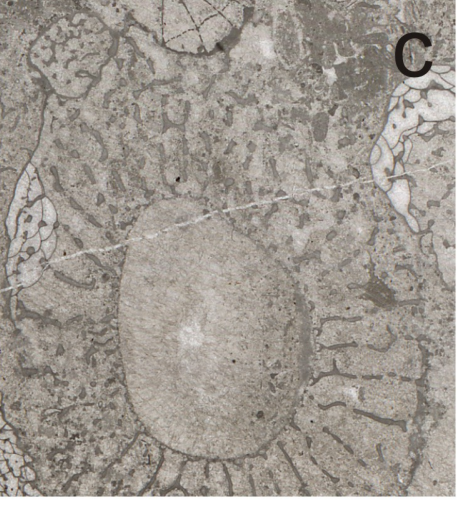

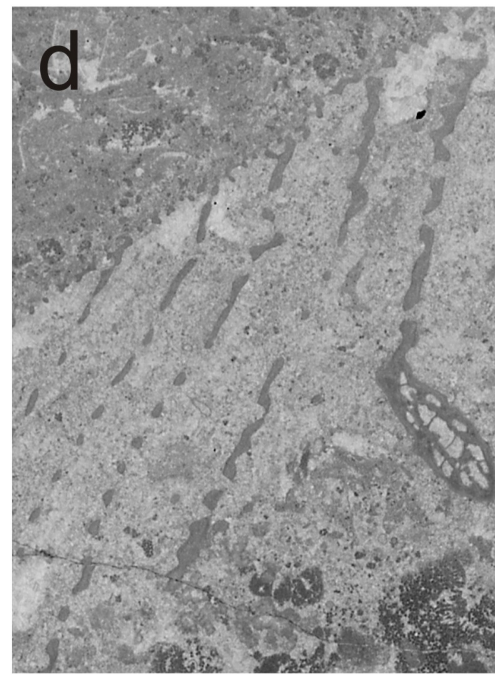

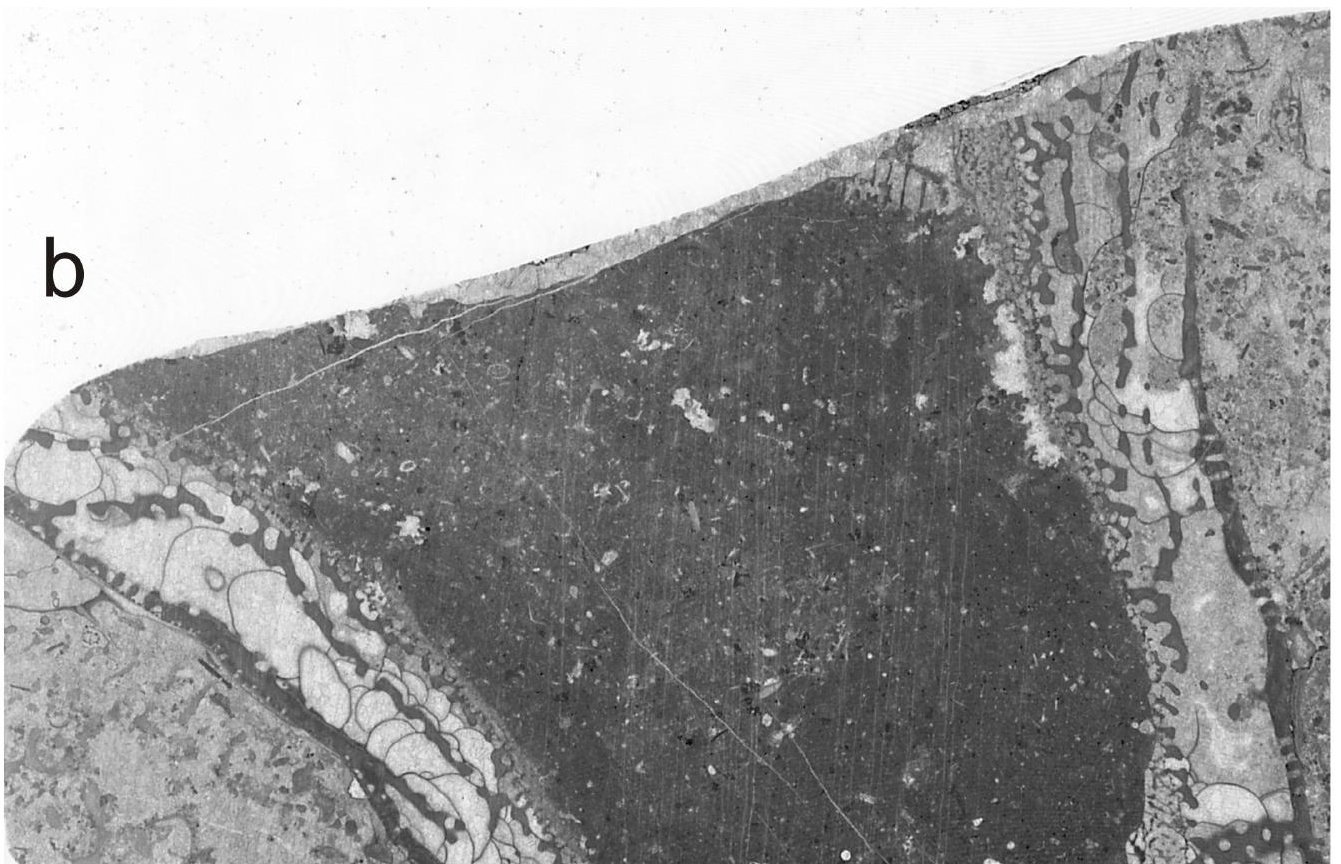




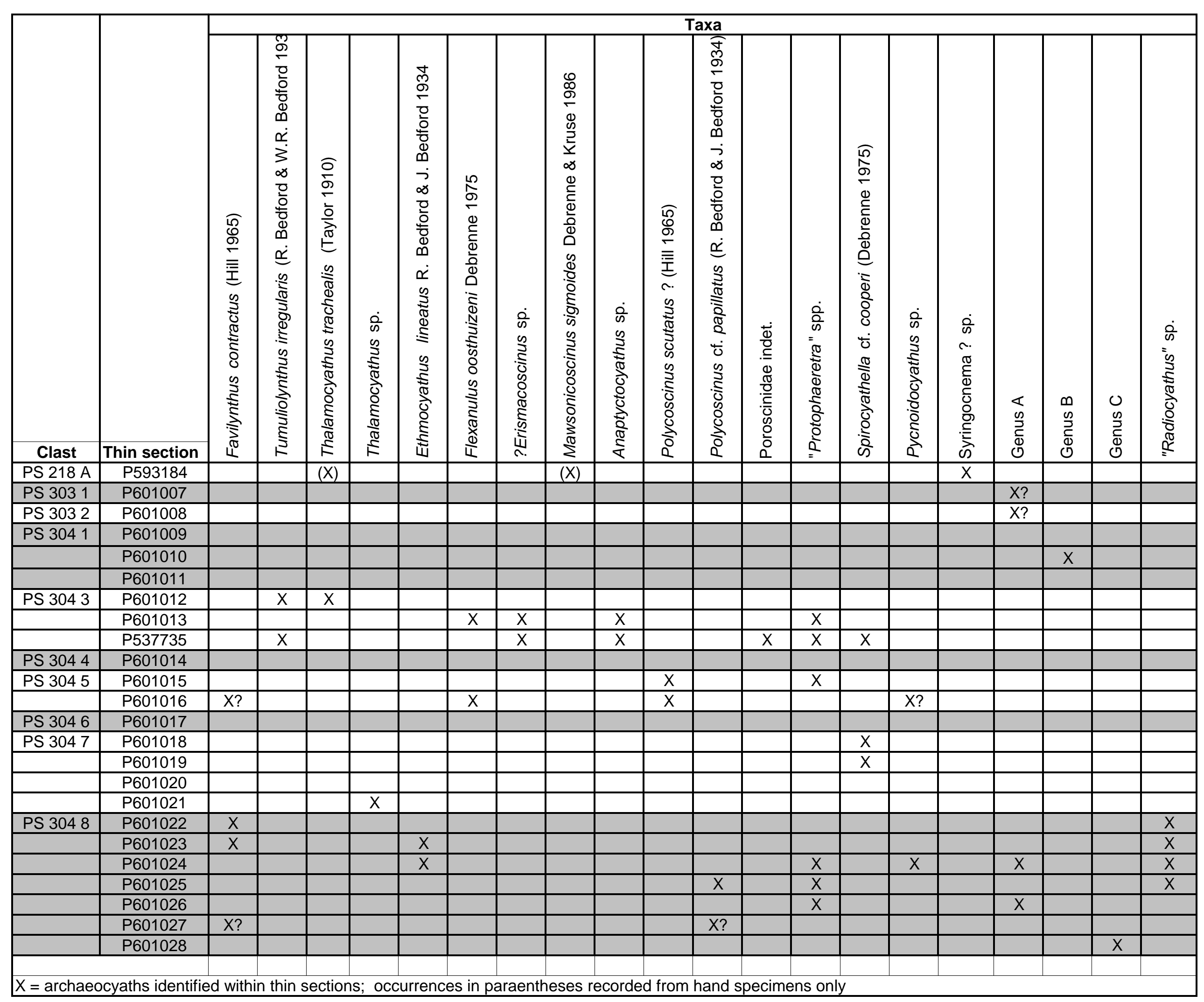




\begin{tabular}{|c|c|c|c|}
\hline Working number & Description & BGS image number & NHM catalogue number \\
\hline \multirow[t]{2}{*}{ PS 218} & HS & P 511905, 511906 & NHM PI PO 12074 \\
\hline & TS & P 593184 & NHM PI PO 12075\$ \\
\hline \multirow[t]{2}{*}{ PS 303-1 } & HS & & NHM PI PO 12076 \\
\hline & TS & P 601007 & NHM PI PO 12077\$ \\
\hline \multirow[t]{2}{*}{ PS 303-2 } & HS & & NHM PI PO 12078 \\
\hline & TS & P 601008 & NHM PI PO 12079\$ \\
\hline PS 304-1 & HS & & NHM PI PO 12080 \\
\hline $304-1 a$ & TS (large) & P 601009 & NHM PI PO 12081\$ \\
\hline $304-1 b$ & TS & P 601010 & NHM PI PO 12082\$ \\
\hline $304-1 c$ & TS & P 601011 & NHM PI PO 12083\$ \\
\hline \multirow[t]{2}{*}{ PS 304-2 } & HS & & NHM PI PO 12084 \\
\hline & TS & & NHM PI PO $12085 \$$ \\
\hline PS 304-3 & HS & & NHM PI PO 12086 \\
\hline $304-3 a$ & TS & P 601012 & NHM PI PO 12087\$ \\
\hline 304-3b & TS & P 601013 & NHM PI PO 12088\$ \\
\hline $304-3 c$ & TS (large) & P 537735 & NHM PI PO 12089\$ \\
\hline $304-3 d$ & TS & & NHM PI PO $12090 \$$ \\
\hline \multirow[t]{2}{*}{ PS 304-4 } & HS & & NHM PI PO 12091 \\
\hline & TS (large) & P 601014 & NHM PI PO $12092 \$$ \\
\hline PS 304-5 & HS & & NHM PI PO 12093 \\
\hline $304-5 a$ & TS & P 601015 & NHM PI PO 12094\$ \\
\hline $304-5 b$ & TS & P 601016 & NHM PI PO 12095\$ \\
\hline \multirow[t]{2}{*}{ PS 304-6 } & HS & & NHM PI PO 12096 \\
\hline & TS & P 601017 & NHM PI PO 12097\$ \\
\hline PS 304-7 & HS & & NHM PI PO 12098 \\
\hline $304-7 a$ & TS & P 601018 & NHM PI PO $12099 \$$ \\
\hline $304-7 a^{1}$ & TS & P 601019 & NHM PI PO 12100\$ \\
\hline $304-7 b$ & TS & P 601020 & NHM PI PO 12101\$ \\
\hline $304-7 c$ & TS & P 601021 & NHM PI PO $12102 \$$ \\
\hline PS 304-8 & HS & & NHM PI PO 12103 \\
\hline $304-8 a$ & TS (large) & P 601022 & NHM PI PO 12104\$ \\
\hline $304-8 a^{1}$ & TS (large) & P 601023 & NHM PI PO 12105\$ \\
\hline $304-8 b$ & TS (large) & P 601024 & NHM PI PO 12106\$ \\
\hline $304-8 b^{1}$ & TS (large) & P 601025 & NHM PI PO 12107\$ \\
\hline $304-8 c$ & TS & P 601026 & NHM PI PO 12108\$ \\
\hline $304-8 d$ & TS & P 601027 & NHM PI PO $12109 \$$ \\
\hline $304-8 \mathrm{e}$ & TS & P 601028 & NHM PI PO 12110\$ \\
\hline
\end{tabular}

